SINAI Journal of Applied Sciences 9 (1) 2020 001-016

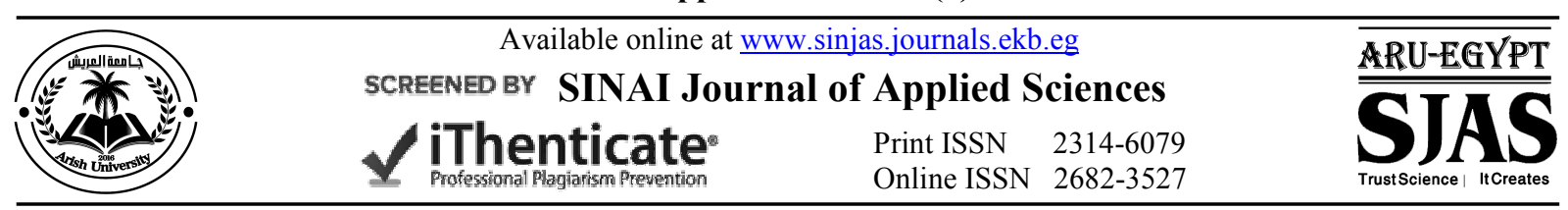

\title{
EFFECT OF IRRIGATION LEVELS AND SOIL AMENDMENT ON GROWTH AND YIELD OF SWEET PEPPER CROP UNDER EL-ARISH REGION CONDITIONS
}

\author{
Taghreed A. Badawi ${ }^{*}$, M.S.A. El-kassas ${ }^{2}$, M.I. Mahmoud ${ }^{1}$, A.I. El-Kassas ${ }^{1}$ \\ 1. Dept. Plant Prod., Fac. Environ. Agric. Sci., Arish Univ. Egypt. \\ 2. Dept. Soil and water, Fac. Environ. Agric. Sci., Arish Univ. Egypt.
}

\begin{tabular}{l} 
ARTICLE INFO \\
\hline Article history: \\
Received: $21 / 02 / 2020$ \\
Revised: $21 / 03 / 2020$ \\
Accepted: $29 / 03 / 2020$ \\
Available online: $01 / 05 / 2020$ \\
\hline Keywords: \\
Capsicum annuum, \\
irrigation levels, \\
soil amendments, \\
gypsum, olive cake, \\
growth parameters, yield. \\
Check for \\
updates
\end{tabular}

\section{INTRODUCTION}

Sweet pepper is an important crop in the Mediterranean area, grown commercially in semi-arid regions. Capsicum has a little energy value but the nutritive value of sweet pepper is high as it contains $1.29 \mathrm{mg}$ protein, $11 \mathrm{mg}$ calcium, 870 I.U vitaminsA, $175 \mathrm{mg}$ ascorbic acid, $0.06 \mathrm{mg}$ thiamine, $0.03 \mathrm{mg}$ riboflavin and $0.55 \mathrm{mg}$ niacin per 100 grams of fruit Joshi and Singh (1975). In addition, pepper is sensitive to drought stress and is moderately sensitive to salt stress Rhoades et al. (1992). Dimitrov and Ovtcharrova (1995) indicated that water deficit, particularly during the period between flowering and fruit development, reduced final fruit production. Marschner (1995) reported that under sufficient water conditions there was a decrease in abscisic acid (AB) and increases in CYT, GA and
IAA reflecting good plant growth and dry matter content.

Define et al. (2000) reported that Capsicum annum L. is one of the most susceptible crops to water stress because of wide transpiring leaf surface and elevated stomatal openings and yet relatively copious amounts of water may be undesirable in terms of resultant fruit yield and quality. The quality of paprika therefore depends on a moisture regime. Also, Palada and O'Keefe (2001) investigated the response of hot pepper cultivars to levels of drip irrigation in the Virgin Islands and observed increasing yield trends with increasing amounts of irrigation water. In addition, Shaozhong et al. (2001), Ismail et al. (2002) and Dorji et al. (2005) found that under water stress conditions, there were reductions in fruit size, number of fruits and fresh fruit yield.

\footnotetext{
* Corresponding author: E-mail address: melkashef82@yahoo.com https://doi.org/10.21608/SINJAS.2020.86367

(C) 2020 SINAI Journal of Applied Sciences. Published by Fac. Environ. Agric. Sci., Arish Univ. All rights reserved.
} 
Abdel-Rheem (2003) reported that increasing levels of irrigation to the soil increased the moisture content that makes minerals more available to the plant that led to enhance mineral concentration and their uptake by plant. Also, Anwar (2005) found that means of water use efficiency (WUE) gradually decreased with increasing water quantity up to the highest level and showed opposite trend to that of total yield, it could be suggest that increasing the quantity of water applied to the soil increases the soil moisture content, that makes the nutritional elements more available to the plant, and this in turn might favored the plant growth characters and most of the physiological process, that directly affect the yield and its components. In addition, higher water quantity applied to plants led to keep higher water content in the plant tissues.

Kirnak et al. (2001) found that the highest amount of proline was found at $40 \%$ by 4.80 and the lowest at $100 \%$ by 2.36 field moisture capacity. Also, Del Amor et al. (2010) found that proline concentration was significantly increased by $41.2 \%$, at moderate stress however, severe drought increased proline from 2.4 to $120.6 \mathrm{~m} \mathrm{~mol} \mathrm{~kg}^{-1}$.

Khan et al. (2009) found that water stress produced lower values of studied parameters (plant height, root length, root volume, leaf dry weight, stem dry weight, and root dry weight), this effect was due to that water stress had negative effect for all the parameters studied of chilli pepper crop. Al-Amran (2010) or Al-Omran et al. (2010) showed that soil water content has specific distribution patterns in amended soil when compared with the control soil in both high and low irrigation rates. Silva et al. (2016) reported that high levels of irrigation $100 \%$ and $80 \%$ had better results of pepper plant compared to other irrigation levels. 60.40 and $20 \%$, there was a $24.44 \%$ increase in the number of leaves in the $80 \%$ when there was reduction of $20 \%$ of water available to the plant, $80 \%$ irrigation level was considered adequate influencing positively the amount of pepper leaves., Also, they found in the number of sheets of the nozzle pepper there was an increase in the number of sheets when there was increased availability of water based on the water requirement $80 \%$ and $100 \%$.

Organic additives offer a simple, sustainable tool for managing agricultural wastes throw converting agricultural waste into a powerful soil enhancer, improve their physicochemical properties, and improves its biological properties. So, increases water holding capacity, cation exchange capacity, available mineral nutrients and this in turn stimulates plant growth and plant productivity. Anwar (2005) reported that soil amendment improved sandy soil characteristics, particularly the available water content, nutrient and improves soil physical and chemical properties that promote nutrient uptake from soil minerals into plants it is reflect of photosynthetic pigments.

Kavdir and Killi (2008) reported that application of olive solid waste (OSW) increased soil total organic nitrogen contents. Also, Alburquerque et al. (2006) reported that olive cake, had high $\mathrm{C} / \mathrm{N}$ ratio. (nearly half of its high organic matter (OM) content was lignin, which is considered to be an important precursor of soil humic substances and responsible for the above-mentioned high $\mathrm{C} / \mathrm{N}$ values, other important constituents were cellulose and hemicellulose). They added that it produces quality end-products, which are non-phytotoxic and rich in partially humified organic matter, and this led to both water and nutrients available for plant which reflected positive effect for plant growth and metabolic.

Gypsum has many benefits, it is a direct source of macro nutrients (calcium and sulfur) for plants, improves soil physical 
and chemical properties that promote nutrient uptake from soil minerals into plants and increases water infiltration and percolation (Norton et al., 1993; Dontsova et al., 2004; Norton, 2008). Saeed and Ahmad (2009) found that application of organic mulch and gypsum helped to increase amount of chlorophyll and carbohydrate biosynthesis.

It is will know that sandy soils have their own problems as very poor soil in mineral nutrients, and has low moisture holding capacity, single grain structure, low levels of microorganisms. Therefore, adding both of organic additives (pressed olive cake) and chemical additives (gypsum) as soil amendments to sandy soil cultivated with pepper plants may help in overcoming some of sandy soil problems in El-Arish region and similar areas. So, this study aimed to solve the problem of water scarcity in El Arish region and improve the growth and yield of pepper plants by using the suitable irrigation level and soil amendment.

\section{MATERIALS AND METHODS}

Two field experiments were carried out during summer season of 2017 and 2018 at the Experimental Farm, Faculty of Environmental Agricultural Sciences, Arish University, Egypt. The aim was studying the effect of irrigation level and soil amendment on growth and productivity of sweet pepper under El-Arish region condition. Initial physical chemical analysis of soil and chemical analysis of irrigation water are presented in Tables 1 and 2.

Soil parameters determined before conducting the experiments were particles size distribution (Piper, 1950), total carbonate (Jackson, 1967) and soil $\mathrm{pH}$ value was determined in 1:2.5 soil water suspension. The soil water extract for the 1:5 soil water ratio was chemically analyzed for electrical conductivity (EC) according to Richard (1954) and Jackson (1967).

The complete Randomized Block Design was used for a factorial experiment contained two factors, the first was irrigation levels (100, 80 and $60 \%$ of irrigation water requirements) and the second was soil amendments (without, agricultural gypsum and pressed olive cake). Sweet pepper seeds of "Top Star" cv. we're transplanting in plastic seedling trays on $14^{\text {th }}$ March and transplanting was carried out on $23^{\text {th }}$ April in both seasons. Plants were irrigated using drip irrigation system, the distance between dripper lines centers was $1.2 \mathrm{~m}$., while the distance between plants in the same row was $50 \mathrm{~cm}$. The plot area was $14.4 \mathrm{~m}^{2}(12 \mathrm{~m}$ length and $1.2 \mathrm{~m}$ wide).

\section{Data Recorded}

At 45, 60 and 75 days after transplanting samples of three plants were randomly taken from each experimental plot to determine vegetative measurements, plant fresh and plant dry weight for leaves and stem. At ripening stage, fruits were harvested and the mean fruit weight, number of fruits per plant, fruit yield per square meter and fruit yield (ton $\mathrm{fad}^{-1}$ ) all for grad A and B as well as total yield (ton fad $^{-1}$ for $\operatorname{grad} \mathrm{A}+\mathrm{B}$ ) were estimated for the marketable yield. Rotten fruits and fruits with more than $20 \%$ of blossom-end rot (BER) were not taken into account for the marketable yield.

\section{Statistical Analysis}

Statistical analysis of the obtained data was carried out according to statistical analysis of variance according to Snedecor and Cochran (1980). Duncan's multiple range tests at 0.05 level was used for comparison among means (Duncan, 1958). 
Badawi et al. | SINAI Journal of Applied Sciences 9 (1) 2020 001-016

Table 1. The initial physical and chemical analyses of the experimental soil site

\begin{tabular}{|c|c|c|}
\hline \multicolumn{3}{|c|}{ Particles size distribution (\%) } \\
\hline & First season 2017 & Second season 2018 \\
\hline Coarse sand (\%) & 58.3 & 58.4 \\
\hline Fine sand $(\%)$ & 19.2 & 19.3 \\
\hline Silt (\%) & 12.3 & 12.0 \\
\hline Clay $(\%)$ & 10.0 & 10.1 \\
\hline Soil texture & Sandy loam & Sandy loam \\
\hline Bulk density $\left(\mathrm{Mgm}^{-3}\right)$ & 1662 & 1661 \\
\hline \multicolumn{3}{|c|}{ Chemical properties (Soluble ions, in 1:5 soil water extract) } \\
\hline $\mathrm{Ca}^{++}\left(\right.$meq. $\left.^{\mathrm{L}-1}\right)$ & 3.90 & 3.90 \\
\hline $\operatorname{Mg}^{++}\left(\right.$meq. $\left.{ }^{\mathrm{L}-1}\right)$ & 3.42 & 3.43 \\
\hline $\mathrm{Na}^{+}\left(\right.$meq. $\left.{ }^{\mathrm{L}-1}\right)$ & 2.74 & 2.55 \\
\hline $\mathrm{K}^{+}\left(\right.$meq. $\left.{ }^{\mathrm{L}-1}\right)$ & 0.34 & 0.32 \\
\hline $\mathrm{CO}_{3}^{-}\left(\right.$meq. $\left.^{\mathrm{L}-1}\right)$ & - & - \\
\hline $\mathrm{HCO}_{3}^{-}\left(\right.$meq. $\left.^{\mathrm{L}-1}\right)$ & 4.50 & 4.40 \\
\hline Cl- (meq. $\left.{ }^{\mathrm{L}-1}\right)$ & 4.40 & 4.35 \\
\hline $\mathrm{SO}_{4}\left(\right.$ meq. $\left.^{\mathrm{L}-1}\right)$ & 1.50 & 1.45 \\
\hline EC (dSm-1) in 1:5 water extract) & 1.04 & 1.03 \\
\hline pH (in1:2.5 Soil water suspension extract) & 8.10 & 8.13 \\
\hline Organic matter $(\%)$ & 0.153 & 0.160 \\
\hline $\mathrm{CaCO}_{3}(\%)$ & 22.43 & 22.48 \\
\hline
\end{tabular}

Table 2. Chemical analysis of irrigation water

\begin{tabular}{|c|c|c|c|c|c|c|c|c|c|}
\hline \multirow{3}{*}{ pH } & \multirow{3}{*}{$\begin{array}{c}E C \\
\left(\mathrm{dSm}^{-1}\right)\end{array}$} & \multicolumn{8}{|c|}{ Soluble ions (meq. ${ }^{\mathrm{L}-1}$ ) } \\
\hline & & \multicolumn{4}{|c|}{ Cations } & \multicolumn{4}{|c|}{ Anions } \\
\hline & & $\mathrm{Ca}^{++}$ & $\mathrm{Mg}^{++}$ & $\mathrm{Na}^{+}$ & $\mathbf{K}^{+}$ & $\mathrm{Cl}^{-}$ & $\mathrm{HCO}_{3-}$ & $\mathrm{CO}_{3--}$ & $\mathrm{SO}_{4--}$ \\
\hline \multicolumn{10}{|c|}{ First season $(2017)$} \\
\hline 7.55 & 5.56 & 19.50 & 17.36 & 18.50 & 0.24 & 45.92 & 2.90 & - & 6.78 \\
\hline \multicolumn{10}{|c|}{ Second season $(\mathbf{2 0 1 8})$} \\
\hline 7.60 & 5.71 & 21.00 & 17.05 & 18.80 & 0.25 & 46.77 & 2.99 & - & 7.34 \\
\hline
\end{tabular}

\section{RESULTS AND DISCUSSION}

\section{Effect of Irrigation Water Levels}

Vegetative growth

Results in Table 3 show significant effects for irrigation levels on vegetative growth traits of sweet pepper plant; viz., plant height, number of leaves and branches as well as leaf area at all sampling dates in both seasons. The highest values of all studied traits were recorded with applying $100 \%$ irrigation level followed by $80 \%$ irrigation level in both seasons at 45, 60 and
75 days after transplanting, except number of branches per plant, where the highest values were recorded with applying 80\% irrigation level followed by $100 \%$ irrigation level in both seasons at 60 and 75 days after transplanting.

It could say that increasing levels of water (quantity) applied led to save higher soil moisture content and this in turn might favored the plant metabolism that leads to increase plant growth characters and produce higher dry matter. On the other hand, water stress led to reduction in the 
Badawi et al. | SINAI Journal of Applied Sciences 9 (1) 2020 001-016

Table 3. Effect of irrigation water levels on vegetative growth of pepper plant at 45, 60 and 75 days after transplanting in 2017 and 2018 seasons

\begin{tabular}{|c|c|c|c|c|c|c|c|c|c|c|c|}
\hline \multirow{3}{*}{ Irrigation water level (\%) } & \multicolumn{3}{|c|}{$\begin{array}{c}\text { Plant height } \\
(\mathrm{cm})\end{array}$} & \multicolumn{3}{|c|}{$\begin{array}{c}\text { No. } \\
\text { Leaves }\end{array}$} & \multicolumn{2}{|c|}{$\begin{array}{c}\text { No. } \\
\text { Branches } \\
\end{array}$} & \multicolumn{3}{|c|}{$\begin{array}{c}\text { Leaf area } \\
\left(\mathbf{m}^{2}\right)\end{array}$} \\
\hline & \multicolumn{11}{|c|}{ Days after transplanting } \\
\hline & 45 & 60 & 75 & 45 & 60 & 75 & 60 & 75 & 45 & 60 & 75 \\
\hline & \multicolumn{11}{|c|}{ First season (2017) } \\
\hline 100 & $28.61 \mathrm{a}$ & $44.27 \mathrm{a}$ & $70.77 \mathrm{a}$ & $29.22 \mathrm{a}$ & $42.83 \mathrm{a}$ & $95.72 \mathrm{a}$ & $1.27 \mathrm{~b}$ & $2.22 \mathrm{~b}$ & $0.119 \mathrm{a}$ & $0.126 \mathrm{a}$ & $0.141 \mathrm{a}$ \\
\hline 80 & $25.38 b$ & $39.16 b$ & $54.00 \mathrm{~b}$ & $25.16 b$ & $38.38 b$ & $70.38 b$ & $1.55 \mathrm{a}$ & $2.38 \mathrm{a}$ & $0.083 b$ & $0.099 \mathrm{~b}$ & $0.138 \mathrm{ab}$ \\
\hline \multirow[t]{2}{*}{60} & $22.22 \mathrm{c}$ & $32.38 \mathrm{c}$ & $45.27 \mathrm{c}$ & $20.77 \mathrm{c}$ & $32.50 \mathrm{c}$ & $42.94 \mathrm{c}$ & $1.05 \mathrm{~b}$ & $2.27 \mathrm{~b}$ & $0.067 \mathrm{c}$ & $0.075 \mathrm{c}$ & $0.135 b$ \\
\hline & \multicolumn{11}{|c|}{ Second season (2018) } \\
\hline 100 & $28.44 \mathrm{a}$ & $44.33 a$ & $70.50 \mathrm{a}$ & $28.38 \mathrm{a}$ & $44.16 \mathrm{a}$ & $93.72 \mathrm{a}$ & $1.16 \mathrm{~b}$ & $2.28 \mathrm{~b}$ & $0.115 \mathrm{a}$ & $0.126 a$ & $0.142 \mathrm{a}$ \\
\hline 80 & $25.61 \mathrm{~b}$ & $39.22 b$ & $53.88 \mathrm{~b}$ & $25.33 b$ & $37.83 b$ & $71.38 \mathrm{~b}$ & $1.61 \mathrm{a}$ & $2.33 \mathrm{a}$ & $0.081 \mathrm{~b}$ & $0.099 b$ & $0.140 \mathrm{ab}$ \\
\hline 60 & $21.83 \mathrm{c}$ & $32.16 \mathrm{c}$ & $45.61 \mathrm{c}$ & $21.16 \mathrm{c}$ & $31.83 \mathrm{c}$ & $43.61 \mathrm{c}$ & $1.00 \mathrm{~b}$ & $2.22 \mathrm{~b}$ & $0.066 \mathrm{c}$ & $0.075 \mathrm{c}$ & $0.135 b$ \\
\hline
\end{tabular}

Values having the same alphabetical letter(s) did not significantly differ at 0.05 level of significance, according to Duncan's multiple range test.

uptake of nutritional elements that might cause a disturbance in the physiological processes of plant growth as reported by (Salter and Goode, 1967). In this direction, El-Beltagy et al. (1984) stated that reduction in the vegetative growth of plants under drought, particularly in shoot growth, reduced cyclin-dependent kinase activity resulting in slower cell division as well as inhibition of growth, and relatively sever reduce in plant tissues (cell size and number of cells per unit or intercellular spaces). In this direction Kandil et al. (2001) reported that drought stress also reduced the uptake of essential elements and photosynthetic capacity. Also, Kirnak et al. (2001) found that water deficit reduced the growth of each plant component, where plant height, stem diameter and dry weight of waterstressed plants were smaller to the equivalent component in the well-watered plants of eggplant. In addition, Abdalla (2011) and Yazdanpanah et al. (2011) reported that water stress leads to increases in abscisic acid levels in roots which is transported from roots to shoot, where it acts in the apical region of the plant as an antagonist of the auxin and cytokinin, responsible for growth and cell division as well as inhibiting DNA synthesis, as well as the excessive accumulation of intermediate compounds such as reactive oxygen species which cause oxidative damage to DNA, lipid and proteins, consequently caused a decrease in plant growth.

\section{Fresh and dry weights}

Results in Tables 4 and 5 show significant effect for levels of irrigation on fresh and dry weights of stem, leaves, and shoot of sweet pepper plant at all sampling dates. The highest values of all studied traits were recorded with applying 100\% irrigation level followed by $80 \%$ irrigation level at 45, 60 and 75 days after planting in both seasons, except fresh and dry weights of branches, where the highest values were recorded with applying 80\% irrigation level followed by $100 \%$ irrigation level at 60 and 75 days after transplanting in both seasons.

These results may be due to that plants had their requirements from water and nutrients with application of $100 \%$ or $80 \%$ levels of irrigation using drip irrigation system. Also, due to that water stress affects carbohydrate metabolism, protein synthesis and the activities of many enzymes that may reflect a change in the balance between 
Badawi et al. | SINAI Journal of Applied Sciences 9 (1) 2020 001-016

Table 4. Effect of irrigation water levels on fresh weight of pepper plant at 45, 60 and 75 days after transplanting in 2017 and 2018 seasons

\begin{tabular}{|c|c|c|c|c|c|c|c|c|c|c|c|}
\hline \multirow{3}{*}{$\begin{array}{c}\text { Irrigation water level } \\
(\%)\end{array}$} & \multicolumn{3}{|c|}{$\begin{array}{c}\text { Stem } \\
(\mathrm{g})\end{array}$} & \multicolumn{3}{|c|}{$\begin{array}{l}\text { Leaves } \\
\text { (g) }\end{array}$} & \multicolumn{2}{|c|}{$\begin{array}{c}\text { Branches } \\
\text { (g) }\end{array}$} & \multicolumn{3}{|c|}{$\begin{array}{c}\text { Shoot } \\
(\text { stem }+ \text { leaves }+ \text { branches }) \\
(\mathrm{g})\end{array}$} \\
\hline & \multicolumn{11}{|c|}{ Days after transplanting } \\
\hline & 45 & 60 & 75 & 45 & 60 & 75 & 60 & 75 & 45 & 60 & 75 \\
\hline & \multicolumn{11}{|c|}{ First season 2017} \\
\hline 100 & $6.28 \mathrm{a}$ & $9.47 \mathrm{a}$ & $15.79 \mathrm{a}$ & $8.03 \mathrm{a}$ & $11.39 \mathrm{a}$ & $15.29 \mathrm{a}$ & $4.18 b$ & $7.91 \mathrm{a}$ & $14.31 \mathrm{a}$ & $25.04 \mathrm{a}$ & $38.99 \mathrm{a}$ \\
\hline 80 & $4.68 b$ & $8.20 b$ & $11.28 \mathrm{~b}$ & $7.11 b$ & $10.17 \mathrm{~b}$ & $11.63 \mathrm{~b}$ & $4.47 \mathrm{a}$ & $8.07 \mathrm{a}$ & $11.79 b$ & $22.84 b$ & $30.98 b$ \\
\hline \multirow[t]{2}{*}{60} & $4.11 \mathrm{c}$ & $6.81 \mathrm{c}$ & $7.87 \mathrm{c}$ & $5.86 \mathrm{c}$ & $8.60 \mathrm{c}$ & $7.09 \mathrm{c}$ & $2.79 \mathrm{c}$ & $6.17 \mathrm{~b}$ & $9.97 \mathrm{c}$ & $18.20 \mathrm{c}$ & $21.13 \mathrm{c}$ \\
\hline & \multicolumn{11}{|c|}{ Second season 2018} \\
\hline 100 & $6.11 \mathrm{a}$ & $9.62 \mathrm{a}$ & $15.89 \mathrm{a}$ & $8.25 \mathrm{a}$ & $11.64 \mathrm{a}$ & $15.63 \mathrm{a}$ & $4.08 \mathrm{~b}$ & $7.96 \mathrm{~b}$ & $14.36 \mathrm{a}$ & $25.34 \mathrm{a}$ & $39.48 \mathrm{a}$ \\
\hline 80 & $4.66 \mathrm{~b}$ & $8.34 b$ & $11.18 b$ & $7.11 b$ & $10.02 b$ & $11.47 \mathrm{~b}$ & $4.42 \mathrm{a}$ & $7.68 \mathrm{a}$ & $11.77 \mathrm{~b}$ & $22.78 b$ & $30.33 b$ \\
\hline 60 & $4.03 c$ & $6.76 c$ & $7.65 c$ & $5.85 \mathrm{c}$ & $8.37 \mathrm{c}$ & $6.97 \mathrm{c}$ & $2.79 \mathrm{c}$ & $6.39 \mathrm{~b}$ & $9.88 \mathrm{c}$ & $17.92 \mathrm{c}$ & $21.01 \mathrm{c}$ \\
\hline
\end{tabular}

Values having the same alphabetical letter(s) did not significantly differ at 0.05 level of significance, according to Duncan's multiple range test.

Table 5. Effect of irrigation water levels on dry weight (g) of pepper plant at 45,60 and 75 days after transplanting in 2017 and 2018 seasons

\begin{tabular}{|c|c|c|c|c|c|c|c|c|c|c|c|}
\hline \multirow{3}{*}{$\begin{array}{c}\text { Irrigation water level } \\
(\%)\end{array}$} & \multicolumn{3}{|c|}{$\begin{array}{l}\text { Stem } \\
(\mathrm{g})\end{array}$} & \multicolumn{3}{|c|}{$\begin{array}{l}\text { Leaves } \\
\text { (g) }\end{array}$} & \multicolumn{2}{|c|}{$\begin{array}{l}\text { Branches } \\
\text { (g) }\end{array}$} & \multicolumn{3}{|c|}{$\begin{array}{c}\text { Shoot } \\
\text { (stem + leaves }+ \text { branches) } \\
\text { (g) }\end{array}$} \\
\hline & \multicolumn{11}{|c|}{ Days after transplanting } \\
\hline & 45 & 60 & 75 & 45 & 60 & 75 & 60 & 75 & 45 & 60 & 75 \\
\hline & \multicolumn{11}{|c|}{ First season (2017) } \\
\hline 100 & $1.08 \mathrm{a}$ & $1.66 \mathrm{a}$ & $3.18 \mathrm{a}$ & $1.38 \mathrm{a}$ & $2.34 \mathrm{a}$ & $3.12 \mathrm{a}$ & $0.83 b$ & $1.61 \mathrm{a}$ & $2.46 \mathrm{a}$ & $4.83 \mathrm{a}$ & $7.91 \mathrm{a}$ \\
\hline 80 & $0.86 \mathrm{~b}$ & $1.44 \mathrm{~b}$ & $2.23 b$ & $1.11 \mathrm{~b}$ & $2.01 \mathrm{~b}$ & $2.29 \mathrm{~b}$ & $0.89 \mathrm{a}$ & $1.58 \mathrm{a}$ & $1.97 \mathrm{~b}$ & $4.34 \mathrm{~b}$ & $6.11 b$ \\
\hline \multirow[t]{2}{*}{60} & $0.73 \mathrm{c}$ & $1.17 \mathrm{c}$ & $1.53 \mathrm{c}$ & $0.84 \mathrm{c}$ & $1.70 \mathrm{c}$ & $1.39 \mathrm{c}$ & $0.55 \mathrm{c}$ & $1.23 b$ & $1.57 \mathrm{c}$ & $3.43 \mathrm{c}$ & $4.15 \mathrm{c}$ \\
\hline & \multicolumn{11}{|c|}{ Second season (2018) } \\
\hline 100 & $1.08 \mathrm{a}$ & $1.62 \mathrm{a}$ & $3.15 \mathrm{a}$ & $1.37 \mathrm{a}$ & $2.27 \mathrm{a}$ & $3.05 \mathrm{a}$ & $0.81 \mathrm{~b}$ & $1.59 \mathrm{a}$ & $2.45 \mathrm{a}$ & $4.71 \mathrm{a}$ & $7.80 \mathrm{a}$ \\
\hline 80 & $0.87 \mathrm{~b}$ & $1.42 \mathrm{~b}$ & $2.25 \mathrm{~b}$ & $1.11 \mathrm{~b}$ & $2.03 b$ & $2.32 \mathrm{~b}$ & $0.88 \mathrm{a}$ & $1.53 \mathrm{a}$ & $1.98 \mathrm{~b}$ & $4.33 b$ & $6.10 \mathrm{~b}$ \\
\hline 60 & $0.73 \mathrm{c}$ & $1.19 \mathrm{c}$ & $1.57 \mathrm{c}$ & $0.85 \mathrm{c}$ & $1.72 \mathrm{c}$ & $1.41 \mathrm{c}$ & $0.55 \mathrm{c}$ & $1.27 \mathrm{~b}$ & $1.58 \mathrm{c}$ & $3.47 \mathrm{c}$ & $4.26 \mathrm{c}$ \\
\hline
\end{tabular}

Values having the same alphabetical letter(s) did not significantly differ at 0.05 level of significance, according to Duncan's multiple range test.

rates of synthesis and degradation leading to decrease in plant growth and dry matter accumulation as reported by Hamlyn (1986). On the other hand, Marschner (1995) reported that under sufficient water conditions there were a decrease in $\mathrm{AB}$ and increase in CYT, GA and IAA reflecting good growth and dry matter content. Also, Kirnak et al. (2001) reported that soil water content either directly or indirectly influences plant growth as well as transpiration rate, since they are mainly turgor-dependent processes. At the onset of stress extension growth and leaf expansion are first affected, followed by a decrease in rates of transpiration due to partial stomatal closure potentially. Also, there were significant reductions in dry matter and chlorophyll content at high water stress compared to the control. In addition, Boutraa (2010) concluded that, water stress conditions cause a multitude of molecular, biochemical and physiological changes, thereby affecting plant growth and development.

Finally, our results are in agreement with Silva et al. (2016) who reported that high levels of irrigation $(100 \%$ and $80 \%)$ had 
better results on pepper plant growth compared to other irrigation levels (60. 40 and $20 \%$ ), where there was a $24.44 \%$ increase in the number of leaves with $80 \%$ level, while there was a reduction of about $20 \%$ of water available to the plant, $80 \%$ irrigation level was considered adequate as influencing positively the number of pepper leaves. Also, they found that in the number of shoots of the nozzle pepper there was an increase in the number of shoots, where there was increased availability of water based on the water requirement of $80 \%$ and $100 \%$ levels.

\section{Yield and its components}

Results in Table 6 show significant effect of irrigation levels on yield and its components; viz., mean fruit weight, and number of fruits per plant for grade $\mathrm{A}$ and $\mathrm{B}$ as well as total yield per faddan. The highest values of total yield and mean fruit weight were recorded with increasing irrigation levels, while the lowest values were recorded with applying $60 \%$ irrigation water level in both seasons.

The increase in total yield was clearly achieved owing to the increases in weight of fruits/plant. This result reflects similar trend to that obtained with plant growth. Also, these results may be due to that increasing levels of irrigation water led to increase the moisture soil content that make the nutritional elements more available to the plant that favored plant growth and most of the physiological processes, that directly affect yield and its components. Additionally, higher water levels applied to plants led to keep higher water content in the plant tissues, that led to increasing plant height and number of branches, resulting in an increase in the number of fruits and total yield.

Results of yield and its components are in agreement with those of Dimitrov and Ovtcharrova (1995) who cleared that water deficit, particularly during the period between flowering and fruit development, reduced final fruit production. Also, results are in agreement with those of Ghosh et al. (2000), El-Banna et al. (2001) Shaozhong et al. (2001), Belanger et al. (2002), Ismail et al. (2002), Dorji et al. (2005), and Fernandez et al. (2005) on pepper plant, who found that under water stress conditions there were a reduction in fruit size, number of fruits and fresh fruit yield. It is meaning that the pepper physiological responses to deficit irrigation were completely negative (Jaimez et al., 2000).

\section{Effect of Soil Amendments}

\section{Vegetative growth}

Results in Table 7 show significant effects for soil amendments on vegetative growth traits; i.e., plant height, number of leaves, and leaf area at all sampling dates, except number of branches in both seasons that had no significant effects. The highest values of all studied traits were recorded with applying olive pressed cake and there was no significant difference between control and gypsum treatment in both seasons.

These result are in agreement with the findings of Kavdir and Killi (2008) who evaluated the effects of olive solid waste (OSW) and OSW compost (OSWC) on tomatoes growth and they found that, application of OSWC increased tomatoes growth; i.e., plant length, dry and fresh weights significantly in sandy and loamy soils, whereas application of OSW increased soil total organic nitrogen contents.

\section{Plant fresh and dry weight}

Results in Tables 8 and 9 show significant effect of soil amendments on fresh and dry weights of stem, leaves, branches and total shoot weight at all sampling dates, except fresh weight of branches that had no significant effect in both seasons. The highest values of all studied traits were recorded with applying olive pressed cake in both seasons at 45, 60 and 75 days after transplanting, these results may be due to that olive cake had high $\mathrm{C} / \mathrm{N}$ ratio (nearly half 
Badawi et al. | SINAI Journal of Applied Sciences 9 (1) 2020 001-016

Table 6. Effect of irrigation water level son marketable fruit yield of pepper plant in 2017 and 2018 seasons

\begin{tabular}{|c|c|c|c|c|c|c|c|c|}
\hline \multirow[b]{2}{*}{ Irrigation water level (\%) } & \multicolumn{3}{|c|}{ Grade A } & \multicolumn{3}{|c|}{ Grade B } & \multicolumn{2}{|c|}{ Total yield } \\
\hline & $\begin{array}{c}\text { Mean fruit } \\
\text { Weight } \\
\text { (g) }\end{array}$ & $\begin{array}{c}\text { No. } \\
\text { Fruits } \\
\left(\mathrm{m}^{2}\right) \\
\end{array}$ & $\begin{array}{c}\text { Yield } \\
\left.\text { (ton fed }{ }^{-1}\right)\end{array}$ & $\begin{array}{c}\text { Mean fruit } \\
\text { weight } \\
\text { (g) }\end{array}$ & $\begin{array}{c}\text { No. } \\
\text { Fruits } \\
\left(\mathbf{m}^{2}\right) \\
\end{array}$ & $\begin{array}{c}\text { Yield } \\
\left.\text { (ton fed }^{-1}\right)\end{array}$ & $\begin{array}{c}\text { No. } \\
\text { Fruits } \\
\left(\mathbf{m}^{2}\right) \\
\end{array}$ & $\begin{array}{c}\text { Yield } \\
\left(\text { ton } \text { fed }^{-1}\right)\end{array}$ \\
\hline & \multicolumn{8}{|c|}{ First season (2017) } \\
\hline 100 & $78.80 \mathrm{a}$ & $43.82 \mathrm{a}$ & $6.04 a$ & $40.98 \mathrm{a}$ & $56.61 \mathrm{a}$ & $4.03 \mathrm{a}$ & $100.44 a$ & $10.07 \mathrm{a}$ \\
\hline 80 & $77.85 \mathrm{a}$ & $39.62 b$ & $5.40 \mathrm{~b}$ & $39.36 \mathrm{c}$ & $52.47 \mathrm{~b}$ & $3.60 \mathrm{~b}$ & $92.10 \mathrm{c}$ & $9.00 \mathrm{~b}$ \\
\hline \multirow[t]{2}{*}{60} & $59.62 b$ & $44.14 \mathrm{a}$ & $4.61 \mathrm{c}$ & $34.08 \mathrm{~b}$ & $51.87 \mathrm{~b}$ & $3.07 \mathrm{c}$ & $96.01 \mathrm{~b}$ & $7.68 \mathrm{c}$ \\
\hline & \multicolumn{8}{|c|}{ Second season (2018) } \\
\hline 100 & $79.26 \mathrm{a}$ & $44.90 \mathrm{a}$ & $6.23 \mathrm{a}$ & $42.13 \mathrm{a}$ & $56.99 \mathrm{a}$ & $4.15 \mathrm{a}$ & $101.90 \mathrm{a}$ & $10.38 \mathrm{a}$ \\
\hline 80 & $79.48 \mathrm{a}$ & $39.82 b$ & $5.54 b$ & $38.57 b$ & $55.18 \mathrm{~b}$ & $3.70 \mathrm{~b}$ & $95.00 \mathrm{~b}$ & $9.24 b$ \\
\hline 60 & $60.86 c$ & $45.01 \mathrm{a}$ & $4.80 \mathrm{c}$ & $34.49 \mathrm{c}$ & $53.42 \mathrm{~b}$ & $3.20 \mathrm{c}$ & $98.43 \mathrm{ab}$ & $8.00 \mathrm{c}$ \\
\hline
\end{tabular}

Values having the same alphabetical letter(s) did not significantly differ at 0.05 level of significance, according to Duncan's multiple range test.

Table 7. Effect of soil amendment on vegetative growth of pepper plant at 45, 60 and 75 days after transplanting in 2017 and 2018 seasons

\begin{tabular}{|c|c|c|c|c|c|c|c|c|c|c|c|}
\hline \multirow[b]{3}{*}{ Amendments } & \multicolumn{3}{|c|}{$\begin{array}{l}\text { Plant height } \\
\text { (cm) }\end{array}$} & \multicolumn{3}{|c|}{$\begin{array}{l}\text { No. } \\
\text { Leaves }\end{array}$} & \multicolumn{2}{|c|}{$\begin{array}{c}\text { No. } \\
\text { Branches }\end{array}$} & \multicolumn{3}{|c|}{$\begin{array}{l}\text { Leaf area } \\
\left(\mathrm{cm}^{2}\right)\end{array}$} \\
\hline & \multicolumn{11}{|c|}{ Days after transplanting } \\
\hline & 45 & 60 & 75 & 45 & 60 & 75 & 60 & 75 & 45 & 60 & 75 \\
\hline & \multicolumn{11}{|c|}{ First season (2017) } \\
\hline $\begin{array}{l}\text { Control (without } \\
\text { amendment) }\end{array}$ & $24.33 b$ & $37.05 b$ & $55.11 \mathrm{~b}$ & $24.66 b$ & $37.05 b$ & $68.77 b$ & $1.33 \mathrm{a}$ & $2.22 \mathrm{a}$ & $0.085 b$ & $0.097 \mathrm{~b}$ & $0.135 b$ \\
\hline Agricultural gypsum & $24.50 \mathrm{~b}$ & $37.55 b$ & $55.55 \mathrm{~b}$ & $23.88 b$ & $35.72 b$ & $66.27 b$ & $1.38 \mathrm{a}$ & $2.27 \mathrm{a}$ & $0.085 b$ & $0.098 \mathrm{~b}$ & $0.142 \mathrm{a}$ \\
\hline \multirow[t]{2}{*}{ Pressed olive cake } & $27.38 \mathrm{a}$ & $41.22 \mathrm{a}$ & $59.38 \mathrm{a}$ & 26.61a & $40.94 a$ & $74.00 \mathrm{a}$ & $1.16 \mathrm{a}$ & $2.38 \mathrm{a}$ & $0.099 \mathrm{a}$ & $0.105 \mathrm{a}$ & $0.137 b$ \\
\hline & \multicolumn{11}{|c|}{ Second season (2018) } \\
\hline $\begin{array}{l}\text { Control (without } \\
\text { amendment) }\end{array}$ & $24.16 b$ & $37.05 b$ & $55.00 \mathrm{~b}$ & $24.61 \mathrm{~b}$ & $37.38 b$ & $68.33 b$ & $1.22 \mathrm{a}$ & $2.35 \mathrm{a}$ & $0.079 b$ & $0.097 \mathrm{~b}$ & $0.137 b$ \\
\hline Agricultural gypsum & $24.50 \mathrm{~b}$ & $37.61 b$ & $55.38 \mathrm{~b}$ & $23.50 \mathrm{~b}$ & $35.94 b$ & $65.88 b$ & $1.27 \mathrm{a}$ & $2.44 \mathrm{a}$ & $0.066 b$ & $0.084 b$ & $0.144 \mathrm{a}$ \\
\hline Pressed olive cake & $27.22 \mathrm{a}$ & $41.05 \mathrm{a}$ & $59.61 \mathrm{a}$ & $26.77 \mathrm{a}$ & $40.50 \mathrm{a}$ & $74.50 \mathrm{a}$ & $1.27 \mathrm{a}$ & $2.44 \mathrm{a}$ & $0.099 \mathrm{a}$ & $0.104 \mathrm{a}$ & $0.136 b$ \\
\hline
\end{tabular}

Values having the same alphabetical letter(s) did not significantly differ at 0.05 level of significance, according to Duncan's multiple range test.

Table 8. Effect of soil amendment on fresh weight of pepper plant at 45, 60 and 75 days after transplanting in 2017 and 2018 seasons

\begin{tabular}{|c|c|c|c|c|c|c|c|c|c|c|c|}
\hline \multirow{3}{*}{ Amendments } & \multicolumn{3}{|c|}{$\begin{array}{l}\text { Stems } \\
(\mathrm{g})\end{array}$} & \multicolumn{3}{|c|}{$\begin{array}{c}\text { Leaves } \\
\text { (g) }\end{array}$} & \multicolumn{2}{|c|}{$\begin{array}{c}\text { Branches } \\
\text { (g) }\end{array}$} & \multicolumn{3}{|c|}{$\begin{array}{c}\text { Shoot } \\
(\text { stem }+ \text { leaves }+ \text { branches }) \\
(\mathrm{g})\end{array}$} \\
\hline & \multicolumn{11}{|c|}{ Days after transplanting } \\
\hline & 45 & 60 & 75 & 45 & 60 & 75 & 60 & 75 & 45 & 60 & 75 \\
\hline & \multicolumn{11}{|c|}{ First season 2017} \\
\hline Control (without amendment) & $4.78 b$ & $7.79 b$ & $11.24 b$ & $6.89 b$ & $9.833 b$ & $11.13 b$ & $3.84 \mathrm{a}$ & $7.17 \mathrm{a}$ & $11.67 \mathrm{~b}$ & $21.46 \mathrm{~b}$ & $29.55 b$ \\
\hline Agricultural gypsum & $4.97 \mathrm{~b}$ & $7.90 \mathrm{~b}$ & $11.07 \mathrm{~b}$ & $6.67 \mathrm{c}$ & $9.447 b$ & $10.74 \mathrm{~b}$ & $3.80 \mathrm{a}$ & $7.30 \mathrm{a}$ & $11.64 \mathrm{~b}$ & $21.15 b$ & $29.12 b$ \\
\hline \multirow[t]{2}{*}{ Pressed olive cake } & $5.32 \mathrm{a}$ & $8.79 \mathrm{a}$ & $12.63 \mathrm{a}$ & $7.45 \mathrm{a}$ & $10.90 \mathrm{a}$ & $12.13 \mathrm{a}$ & $3.80 \mathrm{a}$ & $7.67 \mathrm{a}$ & $12.78 \mathrm{a}$ & $23.49 \mathrm{a}$ & $32.44 \mathrm{a}$ \\
\hline & \multicolumn{11}{|c|}{ Second season 2018} \\
\hline Control (without amendment) & $4.67 b$ & $7.83 b$ & $11.05 b$ & $6.89 b$ & $9.85 b$ & $11.20 \mathrm{~b}$ & $3.7 \mathrm{a}$ & $7.13 \mathrm{a}$ & $11.56 \mathrm{~b}$ & $21.39 b$ & $29.38 b$ \\
\hline Agricultural gypsum & $4.82 \mathrm{~b}$ & $8.05 b$ & $11.11 \mathrm{~b}$ & $6.64 c$ & $9.47 \mathrm{~b}$ & $10.81 \mathrm{~b}$ & $3.77 \mathrm{a}$ & $7.41 \mathrm{a}$ & $11.46 \mathrm{~b}$ & $21.29 b$ & $29.34 b$ \\
\hline Pressed olive cake & $5.32 \mathrm{a}$ & $8.84 \mathrm{a}$ & $12.57 \mathrm{a}$ & $7.68 \mathrm{a}$ & $10.71 \mathrm{a}$ & $12.06 \mathrm{a}$ & $3.81 \mathrm{a}$ & $7.47 \mathrm{a}$ & $13.00 \mathrm{a}$ & $23.37 \mathrm{a}$ & $32.11 \mathrm{a}$ \\
\hline
\end{tabular}

Values having the same alphabetical letter(s) did not significantly differ at 0.05 level of significance, according to Duncan's multiple range test. 
Table 9. Effect of soil amendment on dry weight of pepper plant at 45, 60 and 75 days after transplanting in 2017 and 2018 seasons

\begin{tabular}{|c|c|c|c|c|c|c|c|c|c|c|c|}
\hline \multirow{3}{*}{ Amendments } & \multicolumn{3}{|c|}{$\begin{array}{c}\text { Stems } \\
\text { (g) }\end{array}$} & \multicolumn{3}{|c|}{$\begin{array}{l}\text { Leaves } \\
\text { (g) }\end{array}$} & \multicolumn{2}{|c|}{$\begin{array}{l}\text { Branches } \\
\quad \text { (g) }\end{array}$} & \multicolumn{3}{|c|}{$\begin{array}{c}\text { Shoot } \\
\text { (stem + leaves + branches) } \\
\text { (g) }\end{array}$} \\
\hline & \multicolumn{11}{|c|}{ Days after transplanting } \\
\hline & 45 & 60 & 75 & 45 & 60 & 45 & 60 & 75 & 45 & $\mathbf{6 0}$ & 45 \\
\hline & \multicolumn{11}{|c|}{ First season 2017} \\
\hline Control (without amendment) & $0.87 \mathrm{a}$ & $1.35 \mathrm{~b}$ & $2.21 \mathrm{~b}$ & $1.08 \mathrm{~b}$ & $1.99 \mathrm{~b}$ & $2.24 \mathrm{~b}$ & $0.76 \mathrm{a}$ & $1.43 \mathrm{a}$ & $1.95 \mathrm{~b}$ & $4.11 \mathrm{~b}$ & $5.88 \mathrm{~b}$ \\
\hline Agricultural gypsum & $0.85 \mathrm{a}$ & $1.39 \mathrm{~b}$ & $2.22 \mathrm{~b}$ & $1.01 \mathrm{c}$ & $1.91 \mathrm{~b}$ & $2.16 \mathrm{~b}$ & $0.75 \mathrm{a}$ & $1.46 \mathrm{a}$ & $1.87 \mathrm{~b}$ & $4.06 \mathrm{~b}$ & $5.84 \mathrm{~b}$ \\
\hline \multirow[t]{2}{*}{ Pressed olive cake } & $0.93 \mathrm{a}$ & $1.52 \mathrm{a}$ & $2.51 \mathrm{a}$ & $1.24 \mathrm{a}$ & $2.15 \mathrm{a}$ & $2.41 \mathrm{a}$ & $0.76 \mathrm{a}$ & $1.53 \mathrm{a}$ & $2.18 \mathrm{a}$ & $4.44 a$ & $6.46 \mathrm{a}$ \\
\hline & \multicolumn{11}{|c|}{ Second season 2018} \\
\hline Control (without amendment) & $0.88 \mathrm{a}$ & $1.35 \mathrm{~b}$ & $2.25 \mathrm{~b}$ & $1.08 \mathrm{~b}$ & $1.97 \mathrm{~b}$ & $2.22 \mathrm{~b}$ & $0.74 \mathrm{a}$ & $1.42 \mathrm{a}$ & $1.97 \mathrm{~b}$ & $4.06 \mathrm{~b}$ & $5.90 \mathrm{~b}$ \\
\hline Agricultural gypsum & $0.87 \mathrm{a}$ & $1.35 \mathrm{~b}$ & $2.21 \mathrm{~b}$ & $1.02 \mathrm{c}$ & $1.89 \mathrm{~b}$ & $2.15 \mathrm{~b}$ & $0.75 \mathrm{a}$ & $1.48 \mathrm{a}$ & $1.90 \mathrm{~b}$ & $3.99 \mathrm{~b}$ & $5.84 \mathrm{~b}$ \\
\hline Pressed olive cake & $0.93 \mathrm{a}$ & $1.53 \mathrm{a}$ & $2.52 \mathrm{a}$ & $1.23 \mathrm{a}$ & $2.17 \mathrm{a}$ & $2.42 \mathrm{a}$ & $0.76 \mathrm{a}$ & $1.49 \mathrm{a}$ & $2.16 \mathrm{a}$ & $4.46 \mathrm{a}$ & $6.44 \mathrm{a}$ \\
\hline
\end{tabular}

of its high organic matter (OM) content was lignin, which is considered to be an important precursor of soil humic substances and responsible for the above mentioned high $\mathrm{C} / \mathrm{N}$ values, other important constituents were cellulose and hemicellulose) as reported by Alburquerque et al. (2006) who added that it produces quality end-products, which are non-phytotoxic and rich in partially humified organic matter, and this led to both water and nutrients available for plant which reflected positive effect for plant growth and metabolic process.

\section{Yield and its components}

Results in Table 10 show significant effect for soil amendments on yield and its components; viz., mean fruit weight, number of fruits and yield of grade A and B as well as total yield $\mathrm{fad}^{-1}$. The highest values were recorded with applying pressed olive cake as a soil amendment followed by gypsum, while the lowest values were recorded with control treatment (without soil amendment) in both seasons, except number of fruits of grade B that had the highest value with applying control treatment (no soil amendment), but the mean might of these fruits was the lowest one. On the other hand, there was no significant difference between number of fruits with applying olive pressed cake and control treatments for total yield $\mathrm{fad}^{-1}$, but the mean fruit weight with applying pressed olive cake was higher than control treatment in both seasons.

These results may be due to that olive cake improved sandy soil characteristics, particularly the available water content and nutrient as reported in other studies (Al-Omran et al., 2004, 2005; Sheta et al., 2006). Also, gypsum (calcium sulfate dihydrate) improved sandy soil characteristics due to direct source of macronutrients (calcium and sulfur) for plants and improving soil physical and chemical properties that promote nutrient uptake from soil minerals into plants.

\section{Effect of Interaction between Levels of Irrigation and Soil Amendment}

\section{Vegetative growth}

Results in Table 11 show significant effect for interaction between irrigation, levels and soil amendments on plant growth traits; i.e., plant height, number of leaves, number of branches and leaf area of plant at all sampling dates. The highest values of all studied traits were recorded with applying the levels of $100 \%$ irrigation + pressed olive cake, except number of branches and 
Badawi et al. | SINAI Journal of Applied Sciences 9 (1) 2020 001-016

Table 10. Effect of soil amendments on marketable fruit yield of pepper plant in 2017 and 2018 seasons

\begin{tabular}{|c|c|c|c|c|c|c|c|c|}
\hline \multirow[b]{2}{*}{ Amendment } & \multicolumn{3}{|c|}{ Grade A fruit } & \multicolumn{3}{|c|}{ Grade B fruit } & \multicolumn{2}{|c|}{ Total yield } \\
\hline & $\begin{array}{l}\text { Mean fruit } \\
\text { weight (g) }\end{array}$ & $\begin{array}{l}\text { No. fruits } \\
\left(\mathbf{m}^{-2}\right)\end{array}$ & $\begin{array}{c}\text { Yield -1 } \\
\left.\text { (ton fed. }^{-1}\right)\end{array}$ & $\begin{array}{l}\text { Mean fruit } \\
\text { weight (g) }\end{array}$ & $\begin{array}{c}\text { No. } \\
\text { fruits } \\
\left(\mathbf{m}^{-2}\right)\end{array}$ & $\begin{array}{l}\text { Yield -1 } \\
\text { (ton fed. }^{-1} \text { ) }\end{array}$ & $\begin{array}{l}\text { No. } \\
\text { fruits } \\
\left(\mathrm{m}^{2}{ }^{2}\right)\end{array}$ & $\begin{array}{c}\text { Yield -1 } \\
\text { (ton fed. }^{-1} \text { ) }\end{array}$ \\
\hline & \multicolumn{8}{|c|}{ First season 2017} \\
\hline Control (without amendment) & $69.39 \mathrm{c}$ & $41.77 b$ & $5.06 \mathrm{~b}$ & $34.46 \mathrm{~b}$ & $55.96 \mathrm{a}$ & $3.37 \mathrm{c}$ & $97.73 a$ & $8.43 c$ \\
\hline Agricultural gypsum & $72.00 \mathrm{~b}$ & $42.16 \mathrm{~b}$ & $5.29 b$ & $39.18 \mathrm{a}$ & $51.50 \mathrm{c}$ & $3.53 \mathrm{~b}$ & $93.66 \mathrm{~b}$ & $8.82 b$ \\
\hline \multirow[t]{2}{*}{ Pressed olive cake } & $74.87 \mathrm{a}$ & $43.66 \mathrm{a}$ & $5.70 \mathrm{a}$ & $40.78 \mathrm{a}$ & $53.49 \mathrm{~b}$ & $3.80 \mathrm{a}$ & $97.16 \mathrm{a}$ & $9.51 \mathrm{a}$ \\
\hline & \multicolumn{8}{|c|}{ Second season 2018} \\
\hline Control (without amendment) & $70.11 \mathrm{c}$ & $42.72 b$ & $5.22 \mathrm{c}$ & $35.18 b$ & $57.01 \mathrm{a}$ & $3.48 \mathrm{c}$ & $99.73 a$ & $8.71 \mathrm{c}$ \\
\hline Agricultural gypsum & $73.33 b$ & $42.53 b$ & $5.44 \mathrm{~b}$ & $39.32 \mathrm{a}$ & $53.17 \mathrm{c}$ & $3.63 b$ & $95.70 \mathrm{~b}$ & $9.07 b$ \\
\hline Pressed olive cake & $76.17 \mathrm{a}$ & $44.48 \mathrm{a}$ & $5.90 \mathrm{a}$ & $40.69 \mathrm{a}$ & $55.41 \mathrm{~b}$ & $3.94 \mathrm{a}$ & $99.90 \mathrm{a}$ & $9.84 \mathrm{a}$ \\
\hline
\end{tabular}

Values having the same alphabetical letter(s) did not significantly differ at 0.05 level of significance, according

to Duncan's multiple range test.

Table 11. Effect of interaction between irrigation water levels and soil amendments on vegetative growth of pepper plant at 45,60 and 75 days after transplanting in 2017 and 2018 seasons

\begin{tabular}{|c|c|c|c|c|c|c|c|c|c|c|c|c|}
\hline \multicolumn{2}{|r|}{ Parameter } & \multicolumn{3}{|c|}{$\begin{array}{l}\text { Plant height } \\
\text { (cm) }\end{array}$} & \multicolumn{3}{|c|}{$\begin{array}{c}\text { No. } \\
\text { Leaves }\end{array}$} & \multicolumn{2}{|c|}{$\begin{array}{c}\text { No. } \\
\text { Branches }\end{array}$} & \multicolumn{3}{|c|}{$\begin{array}{c}\text { Leaf area } \\
\left(\mathbf{m}^{2}\right)\end{array}$} \\
\hline \multirow{2}{*}{\multicolumn{2}{|c|}{$\begin{array}{l}\text { Irrigation water } \\
\text { level (\%) }\end{array}$}} & \multicolumn{11}{|c|}{ Days after transplanting } \\
\hline & & 45 & 60 & 75 & 45 & 60 & 75 & 60 & 75 & 45 & 60 & 75 \\
\hline \multirow{4}{*}{100} & & \multicolumn{11}{|c|}{ First season (2017) } \\
\hline & Control (without amendment) & $27.16 b$ & $42.16 b$ & $68.50 \mathrm{~b}$ & $29.50 \mathrm{a}$ & $42.50 \mathrm{ab}$ & $96.50 \mathrm{a}$ & $1.33 \mathrm{ab}$ & $2.16 \mathrm{ab}$ & $0.117 \mathrm{a}$ & $0.122 b$ & $0.135 \mathrm{ab}$ \\
\hline & Agricultural gypsum & $27.16 b$ & $42.50 \mathrm{~b}$ & $69.33 b$ & $27.50 \mathrm{~b}$ & $40.33 \mathrm{bc}$ & $91.33 b$ & $1.33 \mathrm{ab}$ & $2.00 \mathrm{~b}$ & $0.112 \mathrm{a}$ & $0.123 b$ & $0.139 \mathrm{ab}$ \\
\hline & Pressed olive cake & $31.50 \mathrm{a}$ & $48.16 \mathrm{a}$ & $74.50 \mathrm{a}$ & $30.66 \mathrm{a}$ & $45.66 \mathrm{a}$ & $99.33 \mathrm{a}$ & $1.16 \mathrm{a}$ & $2.50 \mathrm{ab}$ & $0.127 \mathrm{a}$ & $0.133 \mathrm{a}$ & $0.137 \mathrm{ab}$ \\
\hline \multirow{3}{*}{80} & Control (without amendment) & $23.66 \mathrm{~cd}$ & $36.50 \mathrm{~d}$ & $51.83 \mathrm{~d}$ & $24.50 \mathrm{c}$ & $38.16 \mathrm{~cd}$ & $69.00 \mathrm{~d}$ & $1.66 \mathrm{~b}$ & $2.00 \mathrm{~b}$ & $0.078 \mathrm{bc}$ & $0.096 \mathrm{~d}$ & $0.138 \mathrm{ab}$ \\
\hline & Agricultural gypsum & $24.16 \mathrm{c}$ & $38.33 \mathrm{c}$ & $52.00 \mathrm{~d}$ & $23.83 \mathrm{c}$ & $35.83 \mathrm{~d}$ & $66.50 \mathrm{~d}$ & $1.66 \mathrm{~b}$ & $2.50 \mathrm{ab}$ & $0.078 \mathrm{bc}$ & $0.097 \mathrm{~d}$ & $0.146 \mathrm{a}$ \\
\hline & Pressed olive cake & $28.33 b$ & $42.66 b$ & $58.16 \mathrm{c}$ & $27.16 \mathrm{~b}$ & $41.16 b c$ & $75.66 \mathrm{c}$ & $1.33 \mathrm{ab}$ & $2.66 \mathrm{a}$ & $0.092 b$ & $0.106 \mathrm{c}$ & $0.140 \mathrm{ab}$ \\
\hline \multirow{3}{*}{60} & Control (without amendment) & $22.16 \mathrm{~d}$ & $32.50 \mathrm{e}$ & $45.00 \mathrm{e}$ & $20.00 \mathrm{e}$ & $30.50 \mathrm{e}$ & $40.83 \mathrm{f}$ & $1.00 \mathrm{~b}$ & $2.50 \mathrm{ab}$ & $0.061 \mathrm{~d}$ & $0.073 \mathrm{e}$ & $0.138 \mathrm{ab}$ \\
\hline & Agricultural gypsum & $22.16 \mathrm{~d}$ & $31.83 \mathrm{e}$ & $45.33 \mathrm{e}$ & $20.33 \mathrm{de}$ & $31.00 \mathrm{e}$ & $41.00 \mathrm{f}$ & $1.16 \mathrm{ab}$ & $2.33 \mathrm{ab}$ & $0.065 \mathrm{~cd}$ & $0.076 \mathrm{e}$ & $0.141 \mathrm{ab}$ \\
\hline & Pressed olive cake & $22.33 \mathrm{~cd}$ & $32.83 \mathrm{e}$ & $45.50 \mathrm{e}$ & $22.00 \mathrm{~d}$ & $36.00 \mathrm{~d}$ & 47.ooe & $1.00 \mathrm{~b}$ & $2.00 \mathrm{~b}$ & $0.076 \mathrm{bcd}$ & $0.076 \mathrm{e}$ & $0.130 \mathrm{~b}$ \\
\hline \multirow{4}{*}{100} & & \multicolumn{11}{|c|}{ Second season (2018) } \\
\hline & Control (without amendment) & $27.33 \mathrm{bc}$ & $42.16 b$ & $68.5 b$ & $28.16 \mathrm{ab}$ & $44.5 \mathrm{ab}$ & $93.16 \mathrm{ab}$ & $1.16 \mathrm{bc}$ & $2.00 \mathrm{~b}$ & $0.102 \mathrm{a}$ & $0.122 \mathrm{a}$ & $0.138 \mathrm{ab}$ \\
\hline & Agricultural gypsum & $26.83 c$ & $43.00 \mathrm{~b}$ & $68.33 b$ & $26.66 \mathrm{bc}$ & $41.66 \mathrm{bc}$ & $89.33 b$ & $1.33 \mathrm{bc}$ & $2.50 \mathrm{ab}$ & $0.114 \mathrm{a}$ & $0.126 \mathrm{a}$ & $0.142 \mathrm{ab}$ \\
\hline & Pressed olive cake & $31.16 \mathrm{a}$ & $47.83 \mathrm{a}$ & $74.66 \mathrm{a}$ & $30.33 \mathrm{a}$ & $46.33 \mathrm{a}$ & $98.66 \mathrm{a}$ & $1.00 \mathrm{c}$ & $2.66 \mathrm{a}$ & $0.130 \mathrm{a}$ & $0.130 \mathrm{a}$ & $0.138 \mathrm{ab}$ \\
\hline \multirow{3}{*}{80} & Control (without amendment) & $23.66 \mathrm{de}$ & $37.33 \mathrm{c}$ & $50.83 \mathrm{e}$ & $25.33 \mathrm{~cd}$ & $37.00 \mathrm{~d}$ & $71.16 \mathrm{~cd}$ & $1.5 \mathrm{ab}$ & $2.00 \mathrm{~b}$ & $0.076 \mathrm{bc}$ & $0.096 \mathrm{~b}$ & $0.135 \mathrm{ab}$ \\
\hline & Agricultural gypsum & $24.50 \mathrm{~d}$ & $37.33 \mathrm{c}$ & $52.83 d$ & $23.33 \mathrm{de}$ & $35.50 \mathrm{~d}$ & $66.83 \mathrm{~d}$ & $1.5 \mathrm{ab}$ & $2.16 \mathrm{ab}$ & $0.074 \mathrm{bc}$ & $0.096 \mathrm{~b}$ & $0.149 \mathrm{ab}$ \\
\hline & Pressed olive cake & $28.66 b$ & $43.00 \mathrm{~b}$ & $58.0 \mathrm{c}$ & $27.33 \mathrm{bc}$ & $41.00 \mathrm{c}$ & $76.16 \mathrm{c}$ & $1.83 \mathrm{a}$ & $2.5 \mathrm{ab}$ & $0.092 b$ & $0.105 b$ & $0.141 \mathrm{a}$ \\
\hline \multirow{3}{*}{60} & Control (without amendment) & $21.50 \mathrm{f}$ & $31.66 \mathrm{~d}$ & $45.66 f$ & $20.33 f$ & $30.66 \mathrm{e}$ & $40.66 f$ & $1.00 \mathrm{c}$ & $2.16 \mathrm{ab}$ & $0.059 \mathrm{~d}$ & $0.074 \mathrm{c}$ & $0.137 \mathrm{ab}$ \\
\hline & Agricultural gypsum & $22.16 \mathrm{ef}$ & $32.50 \mathrm{~d}$ & $45.0 \mathrm{f}$ & $20.50 f$ & $30.66 \mathrm{e}$ & $41.50 \mathrm{f}$ & $1.00 \mathrm{c}$ & $2.66 \mathrm{a}$ & $0.065 \mathrm{~cd}$ & $0.076 \mathrm{c}$ & $0.14 \mathrm{ab}$ \\
\hline & Pressed olive cake & $21.83 \mathrm{f}$ & $32.33 \mathrm{~d}$ & $46.16 f$ & $22.66 \mathrm{ef}$ & $34.16 \mathrm{~d}$ & $48.66 \mathrm{e}$ & $1.00 \mathrm{c}$ & $2.16 \mathrm{ab}$ & $0.075 \mathrm{bcd}$ & $0.076 \mathrm{c}$ & $0.128 b$ \\
\hline
\end{tabular}

Values having the same alphabetical letter(s) did not significantly differ at 0.05 level of probability according to Duncan's multiple range test. 
leaf area where, the highest values were recorded with applying the irrigation level of $80 \%+$ pressed olive cake in the second season at 60 days after planting, while the highest values in the first season were recorded with applying $80 \%+$ pressed olive cake at 75 days after transplanting for number of branches. However, the highest leaf area per plant was recorded with applying 80\% irrigation level + applying gypsum at 60 days after transplanting.

Zotarelli et al. (2009) reported that, general growth and yield of tomato plants subjected to severe water stress were significantly reduced compared to the wellwatered plants. They added that it is possible that at $40 \%$ PC the plant tissues did not get enough water for optimum physiological functioning, also, the uniform distribution and adequate availability of nutrients and moisture in the root zone of sweet pepper. Also, our results are in accordance with the findings of Veeranna et al. (2001) and Kong et al. (2011)

\section{Fresh and dry weight}

Data in Tables 12 and 13 show significant effect for interaction between irrigation levels and soil amendments on stem, leaves, branches and total shoot fresh and dry weights of sweet pepper plant at all sampling dates. The highest values of all studied traits were recorded with applying the level of $100 \%$ irrigation water + pressed olive cake, except fresh weight of branches, where the highest values were recorded with applying the level of $80 \%$ irrigation water + pressed olive cake in the second season at 60 days after transplanting. This result is in agreement with that reported by Anwar (2005).

\section{Yield and its components}

Results in Table 14 show significant effect for interaction between levels of irrigation and soil amendments on yield and its components; i.e., mean fruit weight, number and yield of grade A and B as well as total yield $\mathrm{fad}^{-1}$. It is obvious that the higher values for most traits were with the highest level of irrigation (100\%) followed by $(80 \%)+$ applying pressed olive cake in both seasons, while the lowest value was recorded with the irrigation level of $60 \%+$ with control treatment (without soil amendment).

As regard to values of number of fruits per plant, the highest values of grade A were recorded with $60 \%$ irrigation level in both seasons + gypsum application in the first season or any soil amendment in the second season, while the highest number of fruits for grade B and number of fruits for total yield, were recorded with application of $100 \%$ irrigation level + without soil amendment.

These results may be due to increasing soil water content that led to increasing plant height and number of branches, resulting in an increase in number of fruits and total yield as reported by Antony and Singandhupe (2004). In this direction, Palada and O'Keefe (2001) investigated the response of hot pepper cultivars to levels of drip irrigation in the Virgin Islands and observed increasing yield trends with increasing amounts of irrigation water. Also results are in accordance with Westgate and Boyer (1985), Veeranna et al. (2001) and Sharma et al. (2012) who found reduction in the fresh fruit yield of hot pepper due to deficit irrigation because decreasing the soil water content reduced the fruit size and the total fruit weight of hot pepper, also, dry matter transport in dehydrated plants occurred readily but the total yield was less at the lower level of irrigation. In addition, results are in agreement with Al-Omran et al. (2004, 2005), Sheta et al. (2006) and Kong et al. (2011). 
Badawi et al. | SINAI Journal of Applied Sciences 9 (1) 2020 001-016

Table 12. Effect of inter action between irrigation water level and soil amendments on fresh weight of pepper plant at 45, 60 and 75 days after transplanting in 2017 and 2018 seasons

\begin{tabular}{|c|c|c|c|c|c|c|c|c|c|c|c|c|}
\hline \multicolumn{2}{|r|}{ Parameter } & \multicolumn{3}{|c|}{$\begin{array}{c}\text { Stems } \\
\text { (g) }\end{array}$} & \multicolumn{3}{|c|}{$\begin{array}{c}\text { Leaves } \\
\text { (g) }\end{array}$} & \multicolumn{2}{|c|}{$\begin{array}{c}\text { Branches } \\
\text { (g) }\end{array}$} & \multicolumn{3}{|c|}{$\begin{array}{c}\text { Shoot fresh weigh } \\
\text { (stem + leaves + branches) } \\
(\mathrm{g})\end{array}$} \\
\hline \multirow{2}{*}{\multicolumn{2}{|c|}{$\begin{array}{c}\text { Irrigation water } \\
\text { level }(\%)\end{array}$}} & \multicolumn{11}{|c|}{ Days after transplanting } \\
\hline & & 45 & 60 & 75 & 45 & 60 & 75 & 60 & 75 & 45 & 60 & 75 \\
\hline \multirow{4}{*}{100} & & \multicolumn{11}{|c|}{ First season (2017) } \\
\hline & Control (without amendment) & $6.01 \mathrm{~b}$ & $9.08 \mathrm{~b}$ & $15.32 \mathrm{~b}$ & $8.17 \mathrm{a}$ & $11.27 \mathrm{~b}$ & $15.20 \mathrm{ab}$ & $4.26 \mathrm{a}$ & $7.74 \mathrm{ab}$ & $14.19 \mathrm{~b}$ & $24.62 b$ & $38.26 b$ \\
\hline & Agricultural gypsum & $6.16 \mathrm{~b}$ & $8.93 b$ & $14.77 \mathrm{~b}$ & 7.70ab & $10.66 \mathrm{bc}$ & $14.58 \mathrm{~b}$ & $4.07 \mathrm{a}$ & $7.87 \mathrm{ab}$ & $13.86 \mathrm{~b}$ & $23.66 b$ & $37.22 \mathrm{c}$ \\
\hline & Pressed olive cake & $6.67 \mathrm{a}$ & $10.41 \mathrm{a}$ & $17.30 \mathrm{a}$ & $8.23 \mathrm{a}$ & $12.25 \mathrm{a}$ & $16.09 \mathrm{a}$ & $4.21 \mathrm{a}$ & $8.60 \mathrm{a}$ & $14.91 \mathrm{a}$ & $26.87 \mathrm{a}$ & $41.99 \mathrm{a}$ \\
\hline \multirow{3}{*}{80} & Control (without amendment) & $4.38 \mathrm{de}$ & $7.56 \mathrm{c}$ & $10.51 \mathrm{~d}$ & $6.95 \mathrm{bc}$ & $10.13 \mathrm{~cd}$ & $11.59 \mathrm{~cd}$ & $4.45 \mathrm{a}$ & $7.53 b$ & $11.34 \mathrm{~d}$ & $22.15 \mathrm{c}$ & $29.63 \mathrm{e}$ \\
\hline & Agricultural gypsum & $4.68 \mathrm{~cd}$ & $7.90 \mathrm{c}$ & $10.64 d$ & $6.69 \mathrm{c}$ & $9.47 \mathrm{~d}$ & $10.90 \mathrm{~d}$ & $4.39 \mathrm{a}$ & 7.79ab & $11.37 \mathrm{~d}$ & $21.75 \mathrm{c}$ & $29.34 \mathrm{e}$ \\
\hline & Pressed olive cake & $5.00 \mathrm{c}$ & $9.14 \mathrm{~b}$ & $12.70 \mathrm{c}$ & $7.69 \mathrm{ab}$ & $10.92 \mathrm{bc}$ & $12.40 \mathrm{c}$ & $4.57 \mathrm{a}$ & $8.39 \mathrm{ab}$ & $12.69 \mathrm{c}$ & $24.63 b$ & $33.50 \mathrm{~d}$ \\
\hline \multirow{3}{*}{60} & Control (without amendment) & $3.95 \mathrm{e}$ & $6.73 d$ & $7.91 \mathrm{e}$ & $5.54 \mathrm{~d}$ & $8.08 \mathrm{e}$ & $6.61 \mathrm{f}$ & $2.80 \mathrm{~b}$ & $6.25 \mathrm{c}$ & $9.49 \mathrm{e}$ & $17.62 \mathrm{e}$ & $20.77 f$ \\
\hline & Agricultural gypsum & $4.07 \mathrm{e}$ & $6.88 \mathrm{~d}$ & $7.81 \mathrm{e}$ & $5.62 \mathrm{~d}$ & $8.20 \mathrm{e}$ & $6.75 f$ & $2.95 \mathrm{~b}$ & $6.25 \mathrm{c}$ & $9.69 \mathrm{e}$ & $18.04 \mathrm{e}$ & $20.81 \mathrm{f}$ \\
\hline & Pressed olive cake & $4.31 \mathrm{de}$ & $6.82 \mathrm{~d}$ & $7.89 \mathrm{e}$ & $6.44 \mathrm{c}$ & $9.52 \mathrm{~d}$ & $7.90 \mathrm{e}$ & $2.62 b$ & $6.02 \mathrm{c}$ & $10.75 \mathrm{~d}$ & $18.97 \mathrm{~d}$ & $21.82 \mathrm{f}$ \\
\hline \multirow{4}{*}{100} & & \multicolumn{11}{|c|}{ Second season (2018) } \\
\hline & Control (without amendment) & $5.80 \mathrm{~b}$ & $9.04 \mathrm{~b}$ & $15.02 b$ & $8.18 b$ & $11.72 \mathrm{a}$ & $15.75 \mathrm{a}$ & $3.9 \mathrm{c}$ & $7.43 b$ & $13.99 \mathrm{c}$ & $24.66 b$ & $38.20 \mathrm{~b}$ \\
\hline & Agricultural gypsum & $5.99 \mathrm{~b}$ & $9.39 \mathrm{~b}$ & $15.33 b$ & $7.71 \mathrm{c}$ & $10.94 b$ & $14.93 b$ & $4.19 b c$ & $8.09 \mathrm{ab}$ & $13.70 \mathrm{~b}$ & $24.52 b$ & $38.35 b$ \\
\hline & Pressed olive cake & $6.54 \mathrm{a}$ & $10.43 a$ & $17.34 \mathrm{a}$ & $8.86 \mathrm{a}$ & $12.25 \mathrm{a}$ & $16.22 \mathrm{a}$ & $4.15 b c$ & $8.34 \mathrm{a}$ & $15.41 \mathrm{a}$ & $26.84 \mathrm{a}$ & $41.91 \mathrm{a}$ \\
\hline \multirow{3}{*}{80} & Control (without amendment) & $4.35 \mathrm{~d}$ & $7.82 \mathrm{c}$ & $10.62 d$ & $6.99 \mathrm{~d}$ & $9.78 \mathrm{c}$ & $11.25 \mathrm{~d}$ & $4.43 \mathrm{ab}$ & $7.46 \mathrm{~b}$ & $11.34 \mathrm{~d}$ & $22.02 \mathrm{c}$ & $29.33 d$ \\
\hline & Agricultural gypsum & $4.58 \mathrm{~d}$ & $7.89 \mathrm{c}$ & $10.34 d$ & $6.63 \mathrm{e}$ & $9.41 \mathrm{c}$ & $10.84 d$ & $4.15 b c$ & $7.45 b$ & $11.21 \mathrm{~d}$ & $21.45 \mathrm{c}$ & $28.63 d$ \\
\hline & Pressed olive cake & $5.06 \mathrm{c}$ & $9.31 b$ & $12.59 \mathrm{c}$ & $7.71 \mathrm{c}$ & $10.88 \mathrm{~b}$ & $12.34 \mathrm{c}$ & $4.68 \mathrm{a}$ & $8.13 \mathrm{ab}$ & $12.77 \mathrm{c}$ & $24.88 b$ & $33.05 \mathrm{c}$ \\
\hline \multirow{3}{*}{60} & Control (without amendment) & $3.85 \mathrm{e}$ & $6.64 d$ & $7.50 \mathrm{e}$ & $5.51 \mathrm{~g}$ & $8.05 \mathrm{e}$ & $6.61 \mathrm{f}$ & $2.79 \mathrm{~d}$ & $6.5 \mathrm{~cd}$ & $9.36 \mathrm{e}$ & $17.49 \mathrm{e}$ & $20.61 \mathrm{e}$ \\
\hline & Agricultural gypsum & $3.88 \mathrm{e}$ & $6.86 \mathrm{~d}$ & $7.66 \mathrm{e}$ & $5.58 \mathrm{~g}$ & $8.06 \mathrm{e}$ & $6.68 \mathrm{f}$ & $2.97 \mathrm{~d}$ & $6.7 \mathrm{c}$ & $9.47 \mathrm{e}$ & $17.89 \mathrm{e}$ & $21.04 \mathrm{e}$ \\
\hline & Pressed olive cake & $4.36 \mathrm{~d}$ & $6.78 \mathrm{~d}$ & $7.79 \mathrm{e}$ & $6.46 \mathrm{f}$ & $9.00 \mathrm{~d}$ & $7.63 \mathrm{e}$ & $2.61 \mathrm{~d}$ & $5.95 \mathrm{~d}$ & $10.83 \mathrm{~d}$ & $18.39 \mathrm{~d}$ & $21.38 \mathrm{e}$ \\
\hline
\end{tabular}

Values having the same alphabetical letter(s) did not significantly differ at 0.05 level of probability according to

Duncan's multiple range test.

Table 13. Effect of interaction between irrigation water level and soil amendments on dry weight of pepper plant at 45,60 and 75 days after transplanting in 2017 and 2018 seasons

\begin{tabular}{|c|c|c|c|c|c|c|c|c|c|c|c|c|}
\hline \multicolumn{2}{|r|}{ Parameter } & \multicolumn{3}{|c|}{$\begin{array}{l}\text { Stems } \\
\text { (g) }\end{array}$} & \multicolumn{3}{|c|}{$\begin{array}{l}\text { Leaves } \\
\text { (g) }\end{array}$} & \multicolumn{2}{|c|}{$\begin{array}{l}\text { Branches } \\
\text { (g) }\end{array}$} & \multicolumn{3}{|c|}{$\begin{array}{c}\text { Shoot } \\
(\text { stem }+ \text { leaves }+ \text { branches }) \\
(\mathrm{g})\end{array}$} \\
\hline \multirow{2}{*}{\multicolumn{2}{|c|}{$\begin{array}{l}\text { Irrigation water } \\
\text { level (\%) }\end{array}$}} & \multicolumn{11}{|c|}{ Days after transplanting } \\
\hline & & 45 & 60 & 75 & 45 & 60 & 75 & 60 & 75 & 45 & 60 & 75 \\
\hline & & \multicolumn{11}{|c|}{ First season (2017) } \\
\hline \multirow{3}{*}{100} & Control (without amendment) & $1.03 \mathrm{ab}$ & $1.56 \mathrm{~b}$ & $3.00 \mathrm{~b}$ & $1.37 \mathrm{~b}$ & $2.36 \mathrm{a}$ & $3.15 \mathrm{ab}$ & $0.85 \mathrm{bc}$ & $1.55 \mathrm{ab}$ & $2.39 \mathrm{c}$ & $4.77 b$ & $7.70 \mathrm{~b}$ \\
\hline & Agricultural gypsum & $1.06 \mathrm{ab}$ & $1.62 b$ & $3.06 \mathrm{~b}$ & $1.25 \mathrm{c}$ & $2.21 \mathrm{~b}$ & $2.98 \mathrm{~b}$ & $0.81 \mathrm{bc}$ & $1.57 \mathrm{ab}$ & $2.31 b$ & $4.64 b$ & $7.61 \mathrm{~b}$ \\
\hline & Pressed olive cake & $1.15 \mathrm{a}$ & $1.80 \mathrm{a}$ & $3.46 \mathrm{a}$ & $1.53 \mathrm{a}$ & $2.45 \mathrm{a}$ & $3.24 \mathrm{a}$ & $0.84 \mathrm{bc}$ & $1.72 \mathrm{a}$ & $2.68 \mathrm{a}$ & $5.09 \mathrm{a}$ & $8.43 \mathrm{a}$ \\
\hline \multirow{3}{*}{80} & Control (without amendment) & $0.82 \mathrm{~cd}$ & $1.35 \mathrm{c}$ & $2.12 \mathrm{~d}$ & $1.07 \mathrm{~d}$ & $1.96 \mathrm{c}$ & $2.25 \mathrm{~d}$ & $0.89 \mathrm{ab}$ & $1.50 \mathrm{~b}$ & $1.90 \mathrm{c}$ & $4.20 \mathrm{c}$ & $5.88 \mathrm{~d}$ \\
\hline & Agricultural gypsum & $0.85 \mathrm{c}$ & $1.36 \mathrm{c}$ & $2.06 \mathrm{~d}$ & $1.01 \mathrm{de}$ & $1.90 \mathrm{c}$ & $2.16 \mathrm{~d}$ & $0.87 \mathrm{ab}$ & $1.56 \mathrm{ab}$ & $1.86 \mathrm{c}$ & $4.13 c$ & $5.79 d$ \\
\hline & Pressed olive cake & $0.90 \mathrm{bc}$ & $1.61 \mathrm{~b}$ & $2.51 \mathrm{c}$ & $1.25 \mathrm{c}$ & $2.17 \mathrm{~b}$ & $2.46 \mathrm{c}$ & $0.91 \mathrm{a}$ & $1.68 \mathrm{ab}$ & $2.15 b$ & $4.70 \mathrm{~b}$ & $6.66 \mathrm{c}$ \\
\hline \multirow{3}{*}{60} & Control (without amendment) & $0.77 \mathrm{~cd}$ & $1.15 \mathrm{~d}$ & $1.50 \mathrm{e}$ & $0.80 \mathrm{f}$ & $1.65 \mathrm{~d}$ & $1.32 \mathrm{f}$ & $0.56 \mathrm{~b}$ & $1.24 \mathrm{c}$ & $1.57 \mathrm{~d}$ & $3.36 \mathrm{e}$ & $4.07 \mathrm{c}$ \\
\hline & Agricultural gypsum & $0.66 \mathrm{~d}$ & $1.18 \mathrm{~d}$ & $1.53 \mathrm{e}$ & $0.77 \mathrm{f}$ & $1.63 \mathrm{~d}$ & $1.33 \mathrm{f}$ & $0.59 \mathrm{~b}$ & $1.24 \mathrm{c}$ & $1.44 \mathrm{~d}$ & $3.40 \mathrm{e}$ & $4.11 \mathrm{e}$ \\
\hline & Pressed olive cake & $0.75 \mathrm{~cd}$ & $1.17 \mathrm{~d}$ & $1.56 \mathrm{e}$ & $0.95 \mathrm{e}$ & $1.84 \mathrm{c}$ & $1.52 \mathrm{e}$ & $0.52 \mathrm{~b}$ & $1.20 \mathrm{c}$ & $1.71 \mathrm{c}$ & $3.54 \mathrm{~d}$ & $4.29 \mathrm{e}$ \\
\hline \multirow{4}{*}{100} & & \multicolumn{11}{|c|}{ Second season (2018) } \\
\hline & Control (without amendment) & $1.04 \mathrm{ab}$ & $1.58 \mathrm{~b}$ & $3.06 \mathrm{~b}$ & $1.37 \mathrm{~b}$ & $2.26 \mathrm{ab}$ & $3.04 \mathrm{ab}$ & $0.78 \mathrm{c}$ & $1.48 \mathrm{~b}$ & $2.42 b$ & $4.62 b$ & $7.58 \mathrm{~b}$ \\
\hline & Agricultural gypsum & $1.10 \mathrm{a}$ & $1.49 \mathrm{c}$ & $2.95 b$ & $1.22 \mathrm{c}$ & $2.13 \mathrm{bc}$ & $2.91 \mathrm{~b}$ & $0.84 b c$ & $1.62 \mathrm{ab}$ & $2.32 b$ & $4.46 b$ & $7.49 \mathrm{c}$ \\
\hline & Pressed olive cake & $1.11 \mathrm{a}$ & $1.79 \mathrm{a}$ & $3.46 \mathrm{a}$ & $1.51 \mathrm{a}$ & $2.43 \mathrm{a}$ & $3.21 \mathrm{a}$ & $0.83 b c$ & $1.66 \mathrm{a}$ & $2.62 \mathrm{a}$ & $5.05 \mathrm{a}$ & $8.34 \mathrm{a}$ \\
\hline \multirow{3}{*}{80} & Control (without amendment) & $0.88 \mathrm{ab}$ & $1.3 \mathrm{~d}$ & $2.1 \mathrm{~d}$ & $1.08 \mathrm{~d}$ & $2.02 \mathrm{~cd}$ & $2.32 \mathrm{~cd}$ & $0.88 \mathrm{ab}$ & $1.49 \mathrm{~b}$ & $1.97 \mathrm{c}$ & $4.21 \mathrm{c}$ & $5.91 \mathrm{e}$ \\
\hline & Agricultural gypsum & $0.84 \mathrm{ab}$ & $1.36 \mathrm{~d}$ & $2.12 \mathrm{~d}$ & $1.01 \mathrm{de}$ & $1.89 \mathrm{~d}$ & $2.18 \mathrm{~d}$ & $0.83 \mathrm{bc}$ & $1.49 \mathrm{~b}$ & $1.86 \mathrm{~d}$ & $4.09 \mathrm{c}$ & $5.79 \mathrm{e}$ \\
\hline & Pressed olive cake & $0.89 \mathrm{ab}$ & $1.58 \mathrm{~b}$ & $2.54 \mathrm{c}$ & $1.23 \mathrm{c}$ & $2.17 b c$ & $2.48 \mathrm{c}$ & $0.93 \mathrm{a}$ & $1.62 \mathrm{ab}$ & $2.13 b$ & $4.70 \mathrm{~b}$ & $6.64 d$ \\
\hline \multirow{3}{*}{60} & Control (without amendment) & $0.74 \mathrm{ab}$ & $1.17 \mathrm{e}$ & $1.58 \mathrm{e}$ & $0.80 \mathrm{f}$ & $1.63 \mathrm{e}$ & $1.32 \mathrm{f}$ & $0.55 \mathrm{~d}$ & $1.3 \mathrm{~cd}$ & $1.53 \mathrm{e}$ & $3.35 \mathrm{e}$ & $4.20 \mathrm{f}$ \\
\hline & Agricultural gypsum & $0.67 \mathrm{~b}$ & $1.19 \mathrm{e}$ & $1.56 \mathrm{e}$ & $0.83 \mathrm{f}$ & $1.64 \mathrm{e}$ & $1.35 \mathrm{f}$ & $0.59 \mathrm{~d}$ & $1.34 \mathrm{c}$ & $1.51 \mathrm{e}$ & $3.42 \mathrm{e}$ & $4.24 \mathrm{f}$ \\
\hline & Pressed olive cake & $0.78 \mathrm{ab}$ & $1.21 \mathrm{e}$ & $1.57 \mathrm{e}$ & $0.94 \mathrm{e}$ & $1.9 \mathrm{~d}$ & $1.58 \mathrm{e}$ & $0.52 \mathrm{~d}$ & $1.19 \mathrm{~d}$ & $1.72 \mathrm{~d}$ & $3.63 \mathrm{~d}$ & $4.35 \mathrm{f}$ \\
\hline
\end{tabular}

Values having the same alphabetical letter(s) did not significantly differ at 0.05 level of probability according to

Duncan's multiple range test. 
Badawi et al. | SINAI Journal of Applied Sciences 9 (1) 2020 001-016

Table 14. Effect of interaction between irrigation water levels and soil amendments on marketable fruit yield of sweet pepper plant in 2017 and 2018 seasons

\begin{tabular}{|c|c|c|c|c|c|c|c|c|c|}
\hline \multirow[b]{2}{*}{$\begin{array}{l}\text { Irrigation water } \\
\text { level (\%) }\end{array}$} & \multirow{2}{*}{$\begin{array}{c}\text { Parameter } \\
\text { soil amendment }\end{array}$} & \multicolumn{3}{|c|}{ Grade A fruit } & \multicolumn{3}{|c|}{ Grade B fruit } & \multicolumn{2}{|c|}{ Total yield } \\
\hline & & $\begin{array}{l}\text { Mean fruit } \\
\text { weight (g) }\end{array}$ & $\begin{array}{l}\text { No. fruits } \\
\left(\mathbf{m}^{2}\right)\end{array}$ & $\begin{array}{l}\text { Yield -1 } \\
\text { (ton fed. }^{-1} \text { ) }\end{array}$ & $\begin{array}{c}\text { Mean fruits } \\
\text { weight (g) }\end{array}$ & $\begin{array}{l}\text { No. fruits } \\
\left(\mathbf{m}^{2}\right)\end{array}$ & $\begin{array}{l}\text { Yield -1 } \\
\text { (ton fed. }^{-1} \text { ) }\end{array}$ & $\begin{array}{l}\text { No. fruits } \\
\left(\mathrm{m}^{2}\right)\end{array}$ & $\begin{array}{l}\text { Yield -1 } \\
\text { (ton fed. }^{-1} \text { ) }\end{array}$ \\
\hline & & \multicolumn{8}{|c|}{ First season (2017) } \\
\hline \multirow{3}{*}{100} & Control (without amendment) & $75.50 \mathrm{c}$ & $43.56 \mathrm{ab}$ & $5.75 b$ & & $60.25 \mathrm{a}$ & $3.83 \mathrm{~d}$ & $103.82 \mathrm{a}$ & $9.58 \mathrm{~b}$ \\
\hline & Agricultural gypsum & $79.31 \mathrm{ab}$ & & & & & & & \\
\hline & Pressed olive cake & $.58 \mathrm{a}$ & $44.98 \mathrm{ab}$ & $6.42 \mathrm{a}$ & & $55.81 \mathrm{ab}$ & $4.28 \mathrm{a}$ & $100.79 \mathrm{ab}$ & $10.70 \mathrm{a}$ \\
\hline \multirow{3}{*}{80} & Control (without amendment) & $75.01 \mathrm{c}$ & $38.91 \mathrm{c}$ & $5.10 \mathrm{c}$ & & 53.8 & & $92.71 \mathrm{~cd}$ & $8.50 \mathrm{~cd}$ \\
\hline & Agricultural gypsum & $77.57 \mathrm{bc}$ & $39.30 \mathrm{c}$ & $33 \mathrm{c}$ & $95 \mathrm{ab}$ & $3 c$ & & $90.33 d$ & $8.89 \mathrm{c}$ \\
\hline & Pressed olive cake & $80.96 \mathrm{a}$ & $40.67 \mathrm{c}$ & $5.76 b$ & $88 \mathrm{a}$ & $52.58 b$ & $3.84 b$ & $93.26 \mathrm{~cd}$ & $9.60 \mathrm{~b}$ \\
\hline \multirow{3}{*}{60} & Control (without amendment) & $57.65 \mathrm{e}$ & $42.84 b$ & $4.32 \mathrm{e}$ & $.62 \mathrm{c}$ & $53.83 \mathrm{~b}$ & $2.88 \mathrm{f}$ & $96.67 \mathrm{bcd}$ & $7.20 \mathrm{f}$ \\
\hline & Agricultural gypsum & $59.13 \mathrm{e}$ & $44.24 \mathrm{ab}$ & & & $49.69 \mathrm{~d}$ & 3.05 & $93.93 \mathrm{~cd}$ & $7.63 \mathrm{e}$ \\
\hline & Pressed olive cake & $62.08 \mathrm{~d}$ & $45.35 \mathrm{a}$ & $4.93 \mathrm{c}$ & $36.40 \mathrm{~b}$ & $52.09 \mathrm{~b}$ & $3.28 \mathrm{c}$ & $97.44 \mathrm{bc}$ & $8.21 \mathrm{~d}$ \\
\hline \multirow{4}{*}{100} & \multirow{4}{*}{$\begin{array}{l}\text { Control (without amendment) } \\
\text { Agricultural gypsum } \\
\text { Pressed olive cake } \\
\end{array}$} & \multicolumn{8}{|c|}{ Second season (2018) } \\
\hline & & $76.36 \mathrm{bc}$ & $44.42 \mathrm{a}$ & $5.93 b$ & $37.09 \mathrm{~b}$ & $61.95 \mathrm{a}$ & $3.96 \mathrm{~b}$ & $106.38 \mathrm{a}$ & $9.89 b$ \\
\hline & & $79.41 \mathrm{ab}$ & $44.23 \mathrm{a}$ & $6.15 b$ & $44.17 \mathrm{a}$ & $53.18 \mathrm{~b}$ & $4.10 \mathrm{~b}$ & $97.42 \mathrm{bcd}$ & $10.24 b$ \\
\hline & & $82.03 \mathrm{ab}$ & $46.04 \mathrm{a}$ & $6.61 \mathrm{a}$ & $45.14 \mathrm{a}$ & $55.85 \mathrm{ab}$ & $4.41 \mathrm{a}$ & $101.89 \mathrm{ab}$ & $11.02 \mathrm{a}$ \\
\hline \multirow{3}{*}{80} & Control (without amendment) & $75.83 \mathrm{c}$ & $39.53 b$ & $5.25 \mathrm{c}$ & $36.77 \mathrm{bc}$ & $54.91 \mathrm{ab}$ & $3.50 \mathrm{~cd}$ & $94.44 \mathrm{de}$ & $8.74 \mathrm{c}$ \\
\hline & Agricultural gypsum & $79.57 \mathrm{bc}$ & $39.20 \mathrm{~b}$ & $5.46 \mathrm{c}$ & $38.63 b$ & $54.53 b$ & $3.64 \mathrm{c}$ & $93.73 \mathrm{e}$ & $9.10 \mathrm{c}$ \\
\hline & Pressed olive cake & $83.05 \mathrm{a}$ & $40.74 b$ & $5.92 b$ & $40.3 \mathrm{ab}$ & $56.10 \mathrm{ab}$ & $3.95 b$ & $96.84 \mathrm{~cd}$ & $9.87 \mathrm{~b}$ \\
\hline \multirow{3}{*}{60} & Control (without amendment) & $58.15 \mathrm{e}$ & $44.20 \mathrm{a}$ & $4.49 \mathrm{e}$ & $31.68 \mathrm{c}$ & $54.16 b$ & $3.00 \mathrm{e}$ & $98.37 \mathrm{bcd}$ & $7.49 \mathrm{e}$ \\
\hline & Agricultural gypsum & $61.02 \mathrm{e}$ & $44.15 \mathrm{a}$ & $4.72 \mathrm{e}$ & $35.18 \mathrm{bc}$ & $51.79 \mathrm{c}$ & $3.15 \mathrm{e}$ & $95.95 \mathrm{~cd}$ & $7.86 \mathrm{e}$ \\
\hline & Pressed olive cake & $63.42 \mathrm{a}$ & $46.68 \mathrm{a}$ & $5.18 \mathrm{~d}$ & $36.62 \mathrm{bc}$ & $54.30 \mathrm{~b}$ & $3.45 \mathrm{~d}$ & $100.98 \mathrm{ab}$ & $8.64 d$ \\
\hline
\end{tabular}

Values having the same alphabetical letter(s) did not significantly differ at 0.05 level of probability according to Duncan's multiple range test.

\section{REFERENCES}

Abdalla, M.M. (2011). Beneficial effects of diatomite on the growth, the biochemical contents and polymorphic DNA in Lupinus albus plants grown under water stress. Agric. and Biol. J. North Ame., 2: 207-220

Abdel-Rheem, H.A. (2003). Effect of water stress and potassium fertilization on yield quantity and quality of potato. Ph.D. Thesis, Fac. Agric., Minia Univ., Egypt.

Alburquerque, J.; Gonza'lvez, A.; Garci'a, J.D. and Cegarra, J. (2006). Composting of a solid olive-mill byproduct (alperujo) and the potential of the resulting compost for cultivating pepper under commercial conditions. Waste Manag., 26: 620-626.

Al-Omran, A.M.; Falatah, A.M.; Sheta, A.S. and Al-Harbi, A.R. (2004). Clay deposits for water management of sandy soils. Arid Land Res. Manag., 18: 171183.

Al-Omran, A.M.; Sheta, A.S.; Falatah, A.M. and Al-Harbi, A.R. (2005). Effect of drip irrigation on squash (Cucurbita pepo) yield and water use efficiency in sandy calcareous soils amended with clay deposits. Agric. Water Manag., 73: 43-55.

Al-Omran, A.M.; Al-Harbi, A.R.; WahbAllah, M.A.; Mahmoud, N. and AlEter, Ali (2010). Impact of irrigation water quality, irrigation systems, irrigation rates and soil amendments on tomato production in sandy calcareous soil, Turk. J. Agric.

Antony, E. and Singandhupe, R.B. (2004). Impact of drip and surface irrigation on growth, yield and WUE of capsicum (Capsicum annuum L.), Agric. Water Manag., 65 (2): 121-132. 
Anwar, R.S.E.M. (2005). Response of potato crop to bio fertilizers, irrigation and antitranspirants under sandy soil condition, Ph.D., Thesis Dept. Hort., Fac. Agric., Zagazig Univ., Egypt.

Belanger, G.J.; Walsh, R.; Richard, J.E.; Milbutn, P.H. and Ziadi, N. (2002). Nitrogen fertilization and irrigation affects tuber characteristies of two potato cultivars. Ame. J. Potato Res., 79: 269-279.

Boutraa, T. (2010). Improvement of water use efficiency in irrigated agriculture: A Rev. Agron. J., 9:1-8

Del Amor, F.M.; Cuadra-Crespo, P.; Walker, D.J.; Camara, J.M. and Madrid, C.R. (2010). Effect of foliar application of antitranspirant on photosynthesis and water relations of pepper plants under different levels of $\mathrm{Co}_{2}$ and water stress. J. Plant Physiol., 167: 1232- 1238.

Define, S.; Loreto, F.; Centritto, M.; Santarelli, G. and Alvino, A. (2000). Effects of water stress on the yield and photosynthesis of field-grown sweet pepper (Capsicum annuum L). Acta Hort., 537: 223- 229

Dimitrov, Z. and Ovtcharrova, A. (1995). The productivity of peppers and tomatoes in case of insufficient water supply. In: Proc. ICID Special Tech. Session on the Role of Adv. Technol. Irrigation and Drainage System., 1: 91-95.

Dontsova, K.M.; Norton, L.D.; Johnston, C.T. and Bigham, J.M. (2004). Influence of exchangeable cations on water adsorption by soil clays. Soil Sci. Soc. Ame. J., 68: 1218-1227.

Dorji, K.; Behboudian, M.H. and ZegbeDominguez, J.A. (2005). Water relations, growth, yield, and fruit quality of hot pepper under deficit irrigation and partial root zone drying. Scientia Hort., 104: 137-149.
Duncan, D.B. (1958). Multiple Range and Multiple F test. Biometrics, 11: 1-42.

El-Banna, E.N.; Selim, A.F.H. and Abd El-Salam, H.Z. (2001). Effect of irrigation methods and water regimes on potato plant (Solanum tuberosum L.) under delta soil condition. J. Agric. Sci., Mansoura Univ., 26 (3): 1687-1696.

El-Beltagy, A.S.; El-Said, M.T.; Sawsan, M.H.; Hasniya, M.G. and El-Maksoud, A.A. (1984). Effect of different water regimes on tomato. Ann. Agric. Sci., Ain Shams Univ., 29: 1937-1956

Fernandez, M.D.; Gallardo, M.; Bonachwla, S.; Orgaz, F.; Thompson, R.B. and Fereres, F. (2005). Water use and production of a greenhouse pepper crop under optimum and limited water supply. J. Hort. Sci., 104: 220-247.

Ghosh, S.C.; Asanuma, K.A. and Toyota, M. (2000). Effect of mature stress and different growth stages on the amount of total nonstructural carbohydrate, nitrate reductase activity and yield of potato, Japanese J. Tropical Agric., 44 (3): 158166.

Hamlyn, G.J. (1986). Drought and Drought tolerance in Plants and Microclimate. Comp. Univ. Press, Comp., London, New York, New Rochelle, Melbourne, Sydney, 212-237.

Ismail, M.R.; Davies, W.J. and Mohammad, H.A. (2002). Leaf growth and stomatal sensitivity to ABA in droughted pepper plants. Sci. Hort., 96: 313-327.

Jackson, M.L. (1967). Soil Chemical Analysis. Prentice Hall, Inc., Engle Wood Cliff, N.J.

Jaimez, R.E.; Vielma, O.; Rada, F. and Garcia-Nunez, C. (2000). Effects of water deficit on the dynamics of flowering and fruit production in capsicum chinense jacq in a tropical semiarid region of venezuela. J. Agron. Crop. Sci., 185: 113-119. 
Joshi, M.C. and Singh, D.P. (1975). Chemical Composition in bell pepper. Indian Hort., 20: 19-21.

Kandil, S.A.; Abo-El-Kheir, M.S.A. and El-Zeiny, H.A. (2001). Response of some wheat cultivars to water stress imposed at certain growth stages. Egypt. J. Appl. Sci., 16: 82-98

Kavdir, Y. and Killi, D. (2008). Influence of olive oil solid waste applications on soil $\mathrm{pH}$, electrical conductivity, soil nitrogen transformations, carbon content and aggregate stability. Biores. Technol., 99 (7): 2326-2332.

Khan, M.A.I.; Farooque, A.M.; Hoque, M.A.; Rahim, M.A. and Haque, M.A. (2009). Effect of irrigation levels at different growth stages on growth parameters and yield of four selected chili accessions. Bangladesh J. Agric. Res., 34 (1): 143-155.

Kirnak, H.; Kaya, C.; Tas, I. and Higgs, D. (2001). The influence of water deficit on vegetative growth, physiology, fruit yield and quality in eggplants. Bulg. J. Plant Physiol., 27 (3-4): 34-46.

Kong, Q.; Li, G.; Wang, Y. and Huo, H. (2011). Bell pepper response to surface and subsurface drip irrigation under different fertigation levels. Irrigation. Sci., 11: 271-8.

Marschner, H. (1995). Mineral Nutrition of Higher Plants $2^{\text {nd }}$ (Ed.) Acad. Press Limited, Text Book, 864.

Norton, L.D. (2008). Gypsum soil amendment as a management practice in conservation tillage to improve water quality. J. Soil and Water Conservation, 63: 46A-48A.

Norton, L.D.; Shainberg, I. and King, K.W. (1993). Utilization of gypsiferous amendments to reduce surface sealing in some humid soils of the eastern USA. In: J.W.A. Poesen and M. A. Newaring
(Editors), Soil Surface Sealing and Crusting, Catena Supplement., 24: 77-92.

Palada, M.C. and O'Keefe, D.A. (2001). Response of hot pepper cultivars to levels of drip irrigation in the Virgin Islands. Proc. Caribbean Food Crops Soc., 37: 190-196

Piper, C.S. (1950). Soil and Plant Analysis. Inter. Sci. Publishes, Inc., New York.

Rhoades, J.D.; Kandlah, A. and Mashali, A.M. (1992). The use of saline waters for crop production. FAO Irrig Drain, Paper, 48.

Richard, L.A. (1954). Diagnosis and Improvement of Saline and Alkaline Soils. U.S.D.A. Handbook, 60.

Saeed, R. and Ahmed, A.R. (2009). Vegetative growth and yield of tomato as affected by the application of organic mulch and gypcum under saline rhizosphere, Pak. J. Bot., 41 (6): 30933105.

Salter, P.J. and Goode, T.E. (1967). Crop response to water at different stages of growth. Franham Reyal, Common Welth Agric, Bureaux.

Shaozhong, K.; Xiaotao L.U.Z.; Bhijun, H. and Peter, L.J. (2001). An improved water use efficiency for hot pepper grown under controlled alternate drip irrigation on partial roots. Scientia Hort., 89: 257-267.

Sharma, S.; Halder, A.; Patra, S.K. and Ray, R. (2012). Effect of drip irrigation and nitrogen fertigation on water use efficiency (WUE) and cost economics of guava cv. Khaja. Prog Hort., 44: 136-41.

Sheta, A.S.; Al-Omran, A.M.; Falatah, A.M. and Al-Harbi, A.R. (2006). Effect of clay deposit, physiochemical and intermittent evaporation characteristics of Torripsamment. Arid Land Res. and Manag., 20: 295-307. 
Silva, V.F.; de Lima, V.L.A.; Nascimento, E.C.; De-Andrade, L.O.; Oliveira, H. and Ferreira, A.C. (2016). Effect of different irrigation levels with different qualities of water and organic substrates on cultivation of pepper, Afr. J. Agric. Res., 11 (15): 1373-1380.

Snedecor, G.W. and Cochran, W.G. (1980). Statistical Methods $7^{\text {th }}$ Ed. Iowa State Univ., Press. Ame. Iowa, USA.

Veeranna, H.K.; Kgalak, A.; Faroodhi, A.A. and Sujith, G.M. (2001). Effect of fertigation with normal and water soluble fertilizers compared to drip and furrow methods on yield, fertilizer and irrigation water use efficiency in chilli. Micro. Irrigation, 2: 461-6.
Westgate, M.E. and Boyer, J.S. (1985). Carbohydrate reserves and reproductive development at low water potential in maize, Crop Sci., 25: 752-769

Yazdanpanah, S.; Baghizadeh, A. and Abbassi, F. (2011). The interaction between drought stress and salicylic and ascorbic acids on some biochemical characteristics of Satureja hortensis. Afri. J. Agric. Rese., 6 (4): 798-807.

Zotarelli, L.; Scholberg, J.M.; Dukes, M.D.; Munoz-Carpena, R. and Icerman, J. (2009). Tomato yield, biomass accumulation, root distribution and irrigation water use efficiency on a sandy soil, as affected by nitrogen rate and irrigation scheduling. Agri. Water Man., 9 (6): 23-34.

\section{الملخص العربي \\ تأثير مستويات الري ومحسنات التربة على نمو ومحصول القلقل الحلو تحت ظروف منطقة العريش \\ تغريد علي بدوي'، محمد سعد عبدالحميد القصاص'، محمود ابر اهيم محمود'، علي ابر اهيم القصاص'

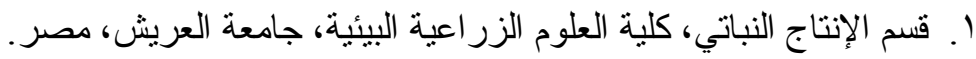

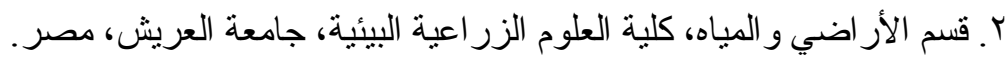

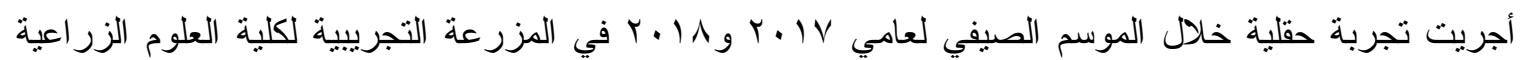

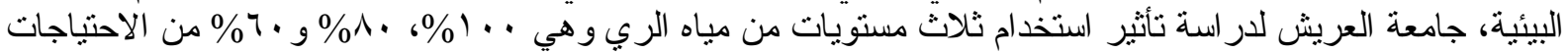

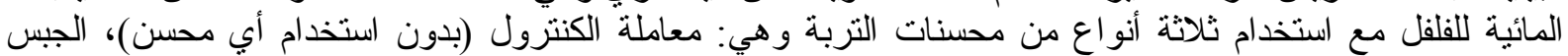

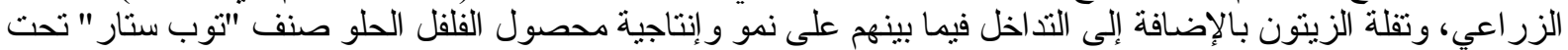

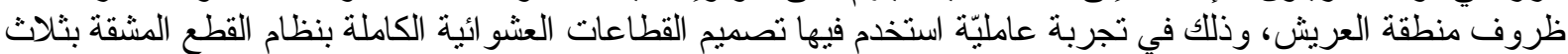

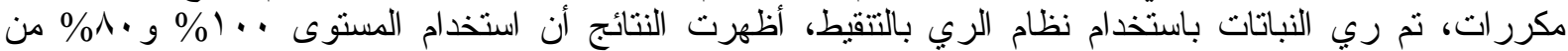

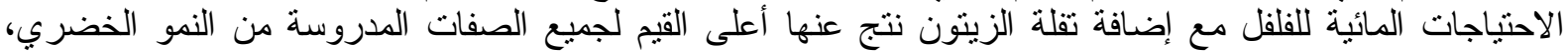

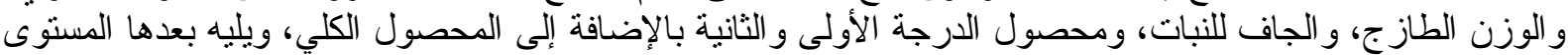

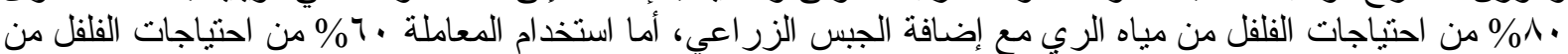

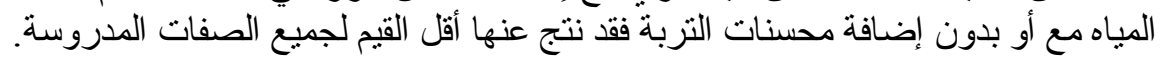
الكلمات الاسترشادية: مستويات الري، محسنات التربة، الجبس الزر اعي، تقلة الزيتون، الفلفل الحلو. 